\author{
Marquette University \\ e-Publications@Marquette
}

$7-2002$

\title{
Synthetic studies directed toward the phorboxazoles: preparation of the C3-C15 bisoxane segment and two stereoisomers
}

\author{
Patrick Bernard Greer \\ Marquette University \\ William Donaldson \\ Marquette University, william.donaldson@marquette.edu
}

Follow this and additional works at: https://epublications.marquette.edu/chem_fac

Part of the Chemistry Commons

\section{Recommended Citation}

Greer, Patrick Bernard and Donaldson, William, "Synthetic studies directed toward the phorboxazoles: preparation of the C3-C15 bisoxane segment and two stereoisomers" (2002). Chemistry Faculty Research and Publications. 67.

https://epublications.marquette.edu/chem_fac/67 
Marquette University

e-Publications@Marquette

\title{
Chemistry Faculty Research and Publications/College of Arts and Sciences
}

This paper is NOT THE PUBLISHED VERSION; but the author's final, peer-reviewed manuscript. The published version may be accessed by following the link in the citation below.

Tetrahedron, Vol. 58, No. 30 (July 22, 2002): 6009-6018. DOI. This article is (C Elsevier and permission has been granted for this version to appear in e-Publications@Marquette. Elsevier does not grant permission for this article to be further copied/distributed or hosted elsewhere without the express permission from Elsevier.

\section{Synthetic Studies Directed Toward the Phorboxazoles: Preparation of The C3-C15 Bisoxane Segment and Two Stereoisomers}

\author{
Patrick B. Greer \\ Department of Chemistry, Marquette University, Milwaukee, WI \\ William A. Donaldson \\ Department of Chemistry, Marquette University, Milwaukee, WI
}

\section{Abstract}

A synthetic approach to the $\mathrm{C} 3-\mathrm{C} 15$ segment of the cytotoxic marine metabolite phorboxazoles is described. This segment consists of a methylene linked bisoxane structure. The first pyran ring was constructed by a Lewis acid catalyzed diene-aldehyde cyclocondensation. The $\beta$ - $C$-glucoside substitution pattern of this ring was established by a stereoselective allylation. Ozonolysis of vinyl group and enantioselective allylation of the racemic aldehyde generated two separable homoallylic alcohols (-)-22 and (+)-23. The Mosher's esters of each alcohol were determined to be $>90 \%$ de. Reaction of (-)-22 with acryloyl chloride, followed by ring closing metathesis gave the dihydro-2-pyrone target (-)-5. Mitsunobu inversion of (+)-23 with $p$-nitrobenzoic 
acid, hydrolysis, and esterification with acryloyl chloride and ring closing metathesis gave pseudoenantiomeric segment (+)-6.

A synthetic approach to the C3-C15 segment of the cytotoxic marine metabolite phorboxazoles is described. The C5-C9 pyran ring was constructed by a Lewis acid catalyzed diene-aldehyde cyclocondensation, while the C11-C15 pyrone ring was constructed by an asymmetric allylation-esterification-ring closing metathesis strategy.

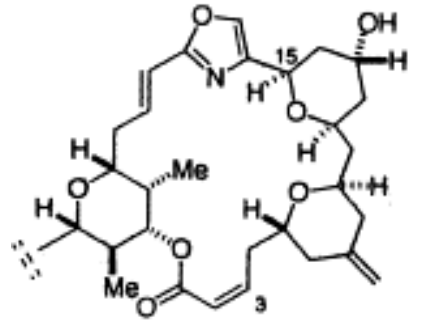

Phorboxazole A

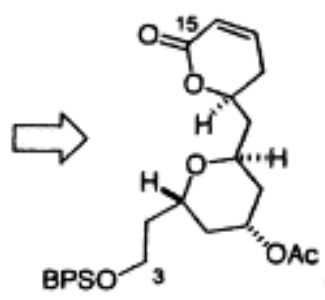

$(-)-5$

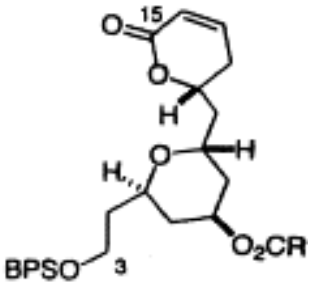

$(+)-6$

\section{Keywords}

Phorboxazoles, C3-C15 bisoxane segment, stereoisomers, phorboxazoles

The phorboxazoles $\mathrm{A}$ and $\mathrm{B}(\mathbf{1} \mathbf{a}$ and $\mathbf{b})$ are isomeric macrolides isolated from the marine sponge Phorbas $\mathrm{sp} .{ }^{1 \mathrm{a}}$ In addition to exhibiting antifungal activity against Candida albicans, both phorboxazoles inhibit the growth of most of the 60 tumor cell lines in the $\mathrm{NCl}$ panel at concentrations $<8 \times 10^{-10} \mathrm{M}$. This level of activity places phorboxazole among the most potent cytostatic agents known. While the exact mechanism of action is unknown, the phorboxazoles do not interfere with tubulin polymerization/depolymerization as is the case for many other antitumor agents (e.g. epothiolone, taxol). Initial results indicate that 1a arrests Burkitt lymphoma CA46 cells in the $S$ phase. ${ }^{1 c}$

The complex structure of 1 consists of four oxane rings, two oxazole rings, 15 asymmetric centers, and a conjugated diene segment. The complete structure was assigned on the basis of NMR spectral studies, Mosher ester data, degradation, and model synthesis. ${ }^{1}$ The outstanding biological activity of $\mathbf{1 a} / \mathbf{b}$, combined with their complex structural architecture, has led to significant activity by a number of research groups, ${ }^{2}$ and three total syntheses. ${ }^{3}$ The three syntheses are all convergent, with the initial preparation of fragments roughly encompassing the $\mathrm{C} 3-\mathrm{C} 15$ bisoxane portion, the $\mathrm{C} 20-\mathrm{C} 27$ oxane ring, and the C31-C46 diene-oxane fragment. Our retrosynthetic strategy disconnects the target into three major fragments, 2-4 (Scheme 1), with connections similar to those reported by Forsyth ${ }^{3 a}$ and by Evans. ${ }^{3 b-d}$ We herein report our detailed study on the enantioselective synthesis of a C3-C15 segment (-)-5, its pseudoenantiomer (+)-6, and the diastereomer (+)7 (Fig. 1). ${ }^{4}$ 


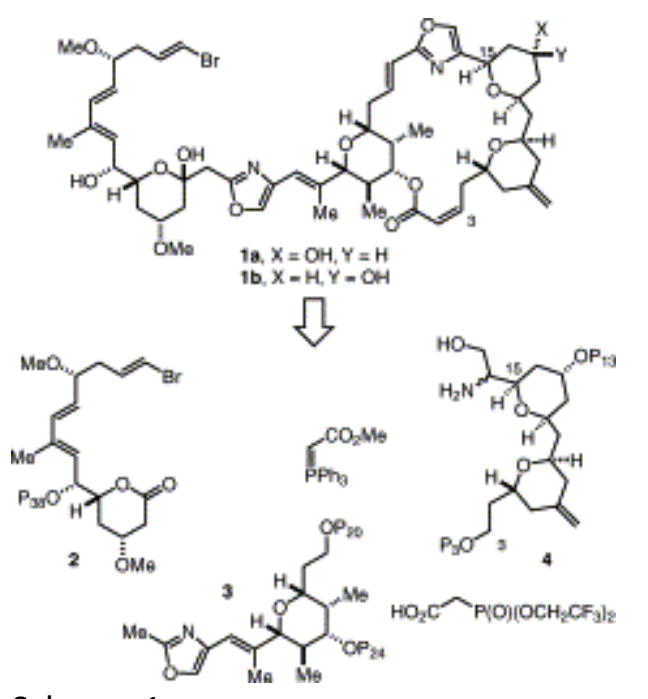

Scheme 1.

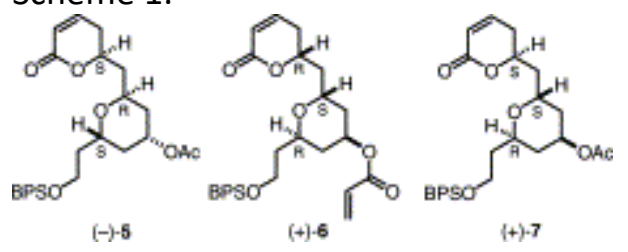

Figure 1.

\section{Results and discussion}

Lewis acid catalyzed diene-aldehyde cyclocondensation ${ }^{5}$ of 8 with 1-methoxy-3-trimethylsilyloxy-1,3-butadiene (9) in the presence of $\mathrm{BF}_{3} \cdot \mathrm{Et}_{2} \mathrm{O}$, followed by brief treatment with $\mathrm{CF}_{3} \mathrm{CO}_{2} \mathrm{H}$ gave dihydropyrone rac-10 (Eq.

(1), Table 1). In a similar fashion, cyclocondensation in the presence of $\mathrm{ZnCl}_{2}$, or $\mathrm{TiCl}_{4}$, or $\mathrm{MgBr}_{2}$ gave the same product. Asymmetric cyclocondensation ${ }^{6 a}$ of 8 with the chiral auxiliary modified diene 1-I-menthyloxy-3-tertbutyldimethylsilyloxy-1,3-butadiene $(\mathbf{1 1})^{6 \mathrm{~b}}$ in the presence of $(+)-\mathrm{Eu}(\mathrm{hfc})_{3}$ (hexane), followed by elimination of methanol gave (5S)-10 in good yield. Unfortunately, comparison of the optical rotation of this product with the literature value $\mathrm{e}^{2 \mathrm{e}}$ indicated that it was only $10 \%$ ee. Cyclocondensation of $\mathbf{8}$ with $\mathbf{9}$ in the presence of the Keck's $R$-BINOL/Ti(iPrO) ${ }_{4} / \mathrm{CF}_{3} \mathrm{CO}_{2} \mathrm{H}$ catalyst ${ }^{7}$ likewise gave (5S)-10 with good enantioselectivity (>90\% ee) albeit in low isolated yield (19\%). Unfortunately in our hands, attempts to optimize the yield of this reaction were unsuccessful.(1)

Table 1. Lewis acid catalyzed diene-aldehyde cyclocondensation

\begin{tabular}{|c|c|}
\hline Lewis acid/rxn conditions & Yield (\%) \\
\hline $\mathrm{BF}_{3} \cdot \mathrm{Et}_{2} \mathrm{O} / \mathrm{Et}_{2} \mathrm{O} /-78^{\circ} \mathrm{C}$ to $\mathrm{rt} / 9 \mathrm{~h}$ & 71 \\
\hline $\mathrm{ZnCl}_{2} / \mathrm{Et}_{2} \mathrm{O} /-78^{\circ} \mathrm{C} / 9 \mathrm{~h}, 23^{\circ} \mathrm{C} / 12 \mathrm{~h}$ & 70 \\
\hline $\mathrm{TiCl}_{4} / \mathrm{Et}_{2} \mathrm{O} / 78^{\circ} \mathrm{C} / 9 \mathrm{~h}, 23^{\circ} \mathrm{C} / 12 \mathrm{~h}$ & 50 \\
\hline $\mathrm{MgBr}_{2} / \mathrm{Et}_{2} \mathrm{O} / 78^{\circ} \mathrm{C} / 9 \mathrm{~h}, 23^{\circ} \mathrm{C} / 12 \mathrm{~h}$ & 31 \\
\hline (+)-Eu(hfc) $)_{3} /$ hexane/rt/24 ha & $52(5 S, 10 \%$ ee $)$ \\
\hline $\mathrm{Ti}(i \mathrm{PrO})_{4} / R-\mathrm{BINOL} / \mathrm{CF}_{3} \mathrm{CO}_{2} \mathrm{H} / \mathrm{Et}_{2} \mathrm{O}$ & $19(5 S, 95 \%$ ee) \\
\hline
\end{tabular}

a1-(1-I-Menthyloxy)-3-(tert-butyldimethylsilyloxy)-1,3-butadiene (11) was used instead of 9.

Reaction of rac-10 with mercuric acetate in methanol, followed by treatment with $\mathrm{NaBH}_{3} \mathrm{CN}$ gave the methyl glycoside 12 (Scheme 2). Compound 12 was assigned the $\beta$-stereochemistry on the basis of the ${ }^{1} \mathrm{H}$ NMR signal for the anomeric proton $(\delta 4.54, \mathrm{dd}, J=2.7,9.0 \mathrm{~Hz})$. The larger coupling constant is consistent with an axial-axial orientation of the anomeric proton with one on the adjacent carbon. Reduction of 12 with $\mathrm{LiAlH}(\mathrm{OtBu})_{3}$ gave the 
equatorial alcohol 13, while reduction of 12 with I-selectride gave a mixture of 13 and the axial alcohol 14 (Scheme 2). The structural assignments for 13 and 14 are based on their ${ }^{1} \mathrm{H}$ NMR spectral data. In particular, the signals for $\mathrm{H} 9$ and $\mathrm{H} 7$ (phorboxazole numbering) of $13(\delta 4.26, \mathrm{dd}, J=1.9,9.5 \mathrm{~Hz}$ and $\delta 3.60, \mathrm{br} \mathrm{m}$, $1 / 2 \mathrm{~W}=26 \mathrm{~Hz}$ ) are consistent with atetrahydropyran bearing all equatorial substituents, while these signals for $14(\delta 4.69, \mathrm{dd}, J=2.1,9.9 \mathrm{~Hz}$ and $\delta 4.31$, pentet, $J=3.0 \mathrm{~Hz})$ are consistent with a $\mathrm{C} 7$ axial hydroxyl group. The diastereoselectivity for reduction of $\beta$-pyranoside ketones under these conditions has been previously reported. ${ }^{8}$

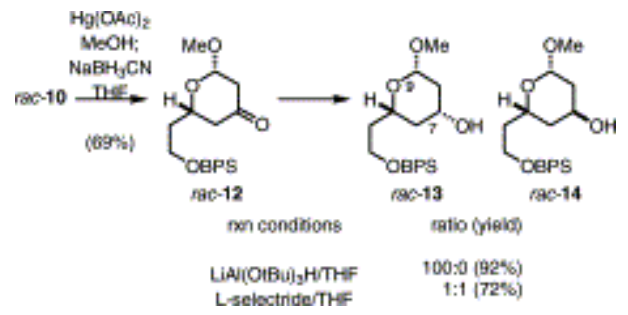

Scheme 2.

Acylation of 13 gave 15 (Scheme 3). Treatment of $\mathbf{1 5}$ with allyl trimethylsilane/ $\mathrm{BF}_{3} \cdot \mathrm{Et}_{2} \mathrm{O}$ gave a separable mixture of $\mathbf{1 6}$ and $\mathbf{1 7}$ (Scheme 3). The ${ }^{1} \mathrm{H}$ NMR spectrum of $\mathbf{1 7}$ is conspicuous in its absence of a signal for the acetate group and by the presence of signals for 5 olefinic protons. In contrast, the ${ }^{1} \mathrm{H}$ NMR spectrum of 16 contains signals at $\delta 5.77(\mathrm{tdd}, 1 \mathrm{H})$ and $5.07-4.80(\mathrm{~m}, 3 \mathrm{H})$ corresponding to the vinyl group and the $\mathrm{C} 7$ proton, and a singlet at $\delta 2.04(3 \mathrm{H})$ corresponding to the acetate methyl. The trans- stereochemistry of the allyl substituent in both 16 and 17 was assigned on the basis of the expected ${ }^{9}$ axial attack of nucleophiles on the cyclic oxonium ion generated from $\mathbf{1 5}$. The formation of $\mathbf{1 7}$ presumably arises from elimination of methanol from $\mathbf{1 5}$ to generate the pseudoglycal 18. A carbon-Ferrier rearrangement of 18 would give the product 17 . Changing the Lewis acid from $\mathrm{BF}_{3} \cdot \mathrm{Et}_{2} \mathrm{O}$ to $\mathrm{TMSOTf}^{10}$ suppressed the formation of $\mathbf{1 7}$; the desired allylpyran $\mathbf{1 6}$ was isolated in $73 \%$ yield.

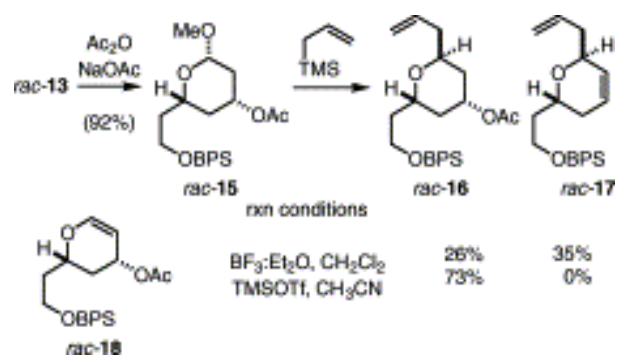

Scheme 3.

Ozonolysis of 16 , followed by treatment of the ozonide with triphenylphosphine, gave the aldehyde rac19 (Scheme 4). Cyclocondensation of $\mathbf{1 9}$ with $\mathbf{9}$ in the presence of $\mathrm{TiCl}_{4}$ gave an inseparable mixture of dihydropyrones 20, which are diastereomeric at C11. The structural assignment for $\mathbf{2 0}$ is based on its ${ }^{1} \mathrm{H}$ NMR spectral data. In particular, the signals corresponding to the C15 proton of the two diastereomers appear at $\delta 7.20$ (d) and 7.17 (d), while the signals corresponding to the C14 proton appear at $\delta 5.36$ (d) and 5.35 (d) ppm. Integration of the C15 signals indicated that the diastereomers were formed in a 2:1 ratio. Cyclocondensation of 19 with 9 in the presence of $\mathrm{ZnCl}_{2}$ or $\mathrm{BF}_{3} \cdot \mathrm{Et}_{2} \mathrm{O}$ in place of $\mathrm{TiCl}_{4}$ gave a similar 2:1 mixture of diastereomers $\mathbf{2 0}$. It was not possible to assign the relative stereochemistry of the major diastereomer of $\mathbf{2 0}$ at C11. 


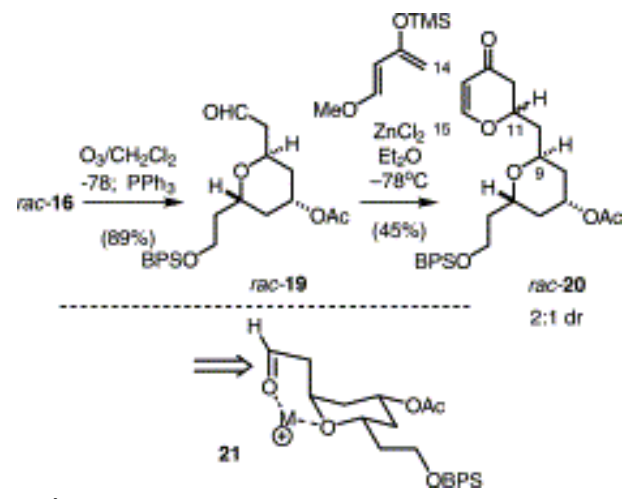

Scheme 4.

Pyranyl aldehydes similar to 19 are known to undergo cyclocondensation with $\mathbf{9}$ with modest diastereoselectivity $(4: 1-5: 1) .{ }^{11}$ In these cases, the major diastereomer possesses the $9 S^{*}, 11 R^{*}$ relative stereochemistry. One rationalization for this stereoselectivity is approach of the silyloxydiene 9 to the less hindered face of a chelated structure (c.f. 21). It should be noted that the $9 S^{*}, 11 R^{*}$ relative stereochemistry is opposite to that desired for the phorboxazoles.

Due to the lack of any significant diastereoselectivity in the cyclocondensation of 19 , it was decided to introduce the C11-C15 pyran ring via sequential allylation-esterification-ring-closing metathesis. ${ }^{12}$ Toward this end, reaction of $r a c-19$ with $B$-allyldiisopinocampheylborane (prepared from (-)-(IPC) $\left.{ }_{2} B O M e\right)$ under salt-free conditions, ${ }^{13}$ followed by oxidative work up with $\mathrm{NaBO}_{3}$, gave a separable mixture of the diastereomers (-)22 and (+)-23 (41 and 42\%, respectively, Eq. (2)). The relative stereochemistry of $\mathbf{2 2}$ and $\mathbf{2 3}$ were assigned by comparison of their ${ }^{13} \mathrm{C}$ NMR spectral data with that of the diastereomeric compounds 24 and 25 (Fig. 2), previously reported by Hoffmann's group. ${ }^{2 m}$ In particular, the spectrum of 22 contains signals at $\delta$ 70.6, 69.7, and $67.2 \mathrm{ppm}(\mathrm{C} 5, \mathrm{C} 9, \mathrm{C} 11$, phorboxazole numbering, specific assignments not intented) while the spectrum of 23 contains signals at $\delta 67.6,67.0$, and 66.8 ppm.(2)

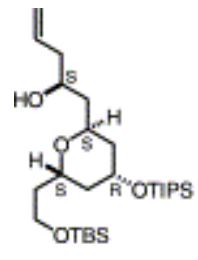

24

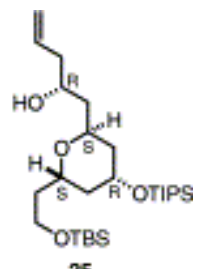

25

Figure 2.

In comparison, the spectrum of 24 contains signals at $\delta 71.2,69.5$, and $67.6 \mathrm{ppm}$, while the spectrum of 25 contains signals at $\delta 67.8,67.0$, and $66.3 \mathrm{ppm}$.

Analysis of the ${ }^{1} \mathrm{H}$ NMR spectra $\left(\mathrm{CDCl}_{3}\right)$ of the $(R)$ - and $(S)$-MTPA esters of 22 indicated separation of the $\mathrm{H}-13$ signals; integration of these signals indicated that the Mosher's esters were $>90 \%$ de. The absolute configuration of 22 at C11 $(S)$ is based on the relative chemical shifts for $\mathrm{H}-13$ signals of the $(R)$ - and (S)-MTPA esters; this signal for the $(R)$ ester appears downfield of that for the $(S)$ ester. ${ }^{14}$ In a similar fashion, integration of the $\mathrm{H}-13$ signals of the $(R)$ - and (S)-MTPA esters of $\mathbf{2 3}$ indicated each to be $>90 \%$ de. The absolute configuration of $\mathbf{2 3}$ at $\mathrm{C} 11(S)$ is based on the relative chemical shifts of these signals; the signal for the $(R)$ ester appears downfield of that for the $(S)$ ester. ${ }^{14}$

Reaction of the diastereomeric alcohols (-)-22 or (+)-23 with acryloyl chloride gave the diastereomeric unsaturated esters (-)-26 or (+)-27 (Scheme 5). ${ }^{15}$ The structures of acrylate esters $\mathbf{2 6}$ and $\mathbf{2 7}$ were assigned on 
the basis of their NMR spectral data. In particular, doublet of doublets signals present at ca. $\delta 6.37,6.09$, and $5.79 \mathrm{ppm}$ in their ${ }^{1} \mathrm{H}$ NMR spectra and resonances at ca. $\delta 165.5,130.5$, and $128.7 \mathrm{ppm}$ in their ${ }^{13} \mathrm{C}$ NMR spectra are characteristic of the acrylate group. Ring closing metathesis ${ }^{16}$ of (-)-26 or (+)-27 in the presence of Grubbs' catalyst gave the dihydropyran-2-ones (-)-5 or (+)-7, respectively. ${ }^{17}$ The structures of 5 and $\mathbf{7}$ were assigned on the basis of their NMR spectral data. In particular, signals present at ca. $\delta 6.7-6.8$ (ddd) and 6.0-5.9 (dd) ppm in their ${ }^{1} \mathrm{H}$ NMR spectra and at ca. $\delta 144.9$ and $121.4 \mathrm{ppm}$ in their ${ }^{13} \mathrm{C}$ NMR spectra are characteristic of the olefin of the dihydropyran-2-one ring.

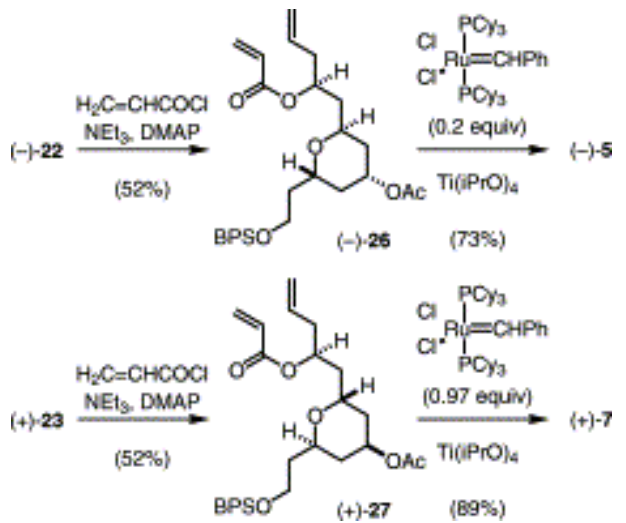

Scheme 5 .

The enantiomers of certain naturally occurring substances fortuitously exhibit interesting biological activity. ${ }^{18}$ It was envisioned that inversion of the $\mathrm{C} 11$ stereocenter present in (+)-23 would generate a molecule enantiomeric with (-)-22. To this end, reaction of $2^{\circ}$ alcohol (+)-23 with $p$-nitrobenzoic acid in the presence of $\mathrm{DEAD} / \mathrm{PPh}_{3}$ proceeded with inversion ${ }^{19}$ to give (+)-28 (Scheme 6). Hydrolysis of both the $p$-nitrobenzoate and acetate esters of (+)-28 gave diol (+)-29. In a similar fashion, hydrolysis of (-)-22 gave the enantiomeric diol (-)29. The ${ }^{1} \mathrm{H}$ and ${ }^{13} \mathrm{C}$ NMR spectra of (+)-29 and (-)-29 were identical. Reaction of (+)-29 with 2 equiv. of acryloyl chloride gave the bis-acrylate ester (+)-30. Ring closing metathesis of the bis-acrylate $(+)-30$ proceeded only via formation of the six-membered dihydropyran-2-one ring to give (+)-6.

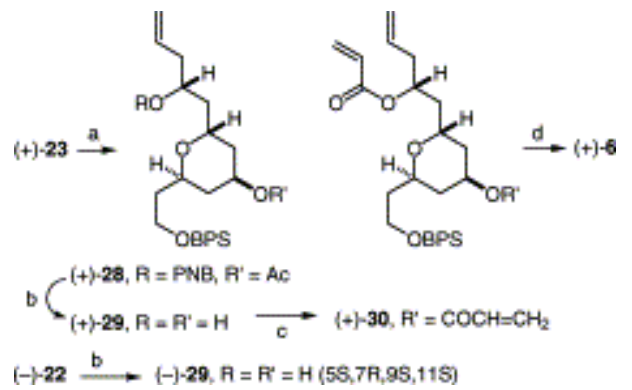

Scheme 6. Reagents (a) $p-\mathrm{NO}_{2} \mathrm{PhCO}_{2} \mathrm{H}$, DEAD, $\mathrm{PPh}_{3}$ (51\%); (b) $\mathrm{K}_{2} \mathrm{CO}_{3}, \mathrm{MeOH}$ (72-88\%); (c) $\mathrm{H}_{2} \mathrm{C}$ CHCOCl, $\mathrm{NEt}_{3}$, $\operatorname{DMAP}(43 \%) ;(\mathrm{d}) \mathrm{Ru}(\mathrm{CHPh})\left(\mathrm{PCy}_{3}\right)_{2} \mathrm{Cl}_{2}$ (0.07 equiv.), $\mathrm{Ti}(i \mathrm{PrO})_{4}, \mathrm{CH}_{2} \mathrm{Cl}_{2}(79 \%)$.

In summary, the C3-C15 segment of the phorboxazoles (in the form of optically active dihydropyran-2-one (-)-5) was prepared in 9 steps from the known aldehyde $\mathbf{8}$ via the alcohol (-)-22. The presence of the $\alpha, \beta$-unsaturated lactone should allow for introduction of the requisite $\mathrm{C} 13$ hydroxyl substituent ${ }^{12 \mathrm{~b}}$ and the $\mathrm{C} 15-\mathrm{C} 16$ bond in a stereoselective fashion. Additionally, the enantiomeric segment (+)-6 was prepared from (+)-23. 


\section{Experimental}

\subsection{General data}

Spectrograde solvents were used without purification with the exception of dry ether and dry THF which were distilled from sodium benzophenone ketyl and dichloromethane which was distilled from $\mathrm{P}_{2} \mathrm{O}_{5}$ and then stored over molecular seives. Anhydrous hexane and anhydrous toluene were purchased from Aldrich. Column chromatography was performed on silica gel 60 (60-200 mesh, Aldrich). Melting points were obtained on a MelTemp melting point apparatus and are uncorrected. All ${ }^{1} \mathrm{H}$ and ${ }^{13} \mathrm{C}$ NMR spectra were recorded at 300 and $75 \mathrm{MHz}$, respectively. Elemental analyses were obtained from Midwest Microlabs, Indianapolis, IN and high resolution mass spectra were obtained from the Washington University Resource for Biomedical and Bioorganic Mass Spectrometry.

\subsubsection{Dihydropyrone (10)}

To a solution of 3-(tert-butyldi-phenylsilyloxy)propanal ${ }^{20}(8,11.42 \mathrm{~g}, 36.5 \mathrm{mmol})$ in ether $(75 \mathrm{~mL})$ cooled to $-78^{\circ} \mathrm{C}$ was added dropwise 1-methoxy-3-trimethylsilyloxy-1,3-butadiene $(9,10.0 \mathrm{~g}, 5.80 \mathrm{mmol})$ in ether $(25 \mathrm{~mL})$. After stirring for $5 \mathrm{~min}, \mathrm{BF}_{3} \cdot \mathrm{Et}_{2} \mathrm{O}(7 \mathrm{~mL}, 56.9 \mathrm{mmol})$ was added dropwise over a 5 min period. The mixture was stirred for $9 \mathrm{~h}$ during which it was slowly warmed to rt. Saturated aqueous $\mathrm{NaHCO}_{3}$ was added, the reaction was stirred for $30 \mathrm{~min}$, and then extracted with ether $(3 \times 75 \mathrm{~mL})$. The combined organic layers were dried $\left(\mathrm{MgSO}_{4}\right)$ and the solvent evaporated to afford a reddish brown oil. This residue was dissolved in $\mathrm{CH}_{2} \mathrm{Cl}_{2}(100 \mathrm{~mL})$, trifluoroacetic acid (7 drops) was added, and the mixture stirred for $18 \mathrm{~h}$ at rt. Saturated aqueous $\mathrm{NaHCO}_{3}$ was added, the mixture stirred for $30 \mathrm{~min}$, the layers separated, and the aqueous layer extracted with $\mathrm{CH}_{2} \mathrm{Cl}_{2}(4 \times 75 \mathrm{~mL})$. The combined organic layers were dried $\left(\mathrm{MgSO}_{4}\right)$ and the solvent evaporated. The residue was purified by chromatography (hexane-ethyl acetate=9:1) to give $\mathbf{1 0}$ as a colorless oil (9.879 g, $71 \%) ;{ }^{1} \mathrm{H}$ NMR $\left(\mathrm{CDCl}_{3}\right)$ \& 7.66-7.63 (m, 4H), 7.47-7.37 (m, 6H), $7.29(\mathrm{~d}, \mathrm{~J}=6.0 \mathrm{~Hz}, 1 \mathrm{H}), 5.40$ (d, J=6.2 Hz, 1H), 4.67 (tdd, J=4.4, 8.6, $12.7 \mathrm{~Hz}, 1 \mathrm{H}), 3.90-3.74(\mathrm{~m}, 2 \mathrm{H}), 2.59-2.42(\mathrm{~m}, 2 \mathrm{H}), 2.08-1.97(\mathrm{~m}, 1 \mathrm{H}), 1.93-1.83(\mathrm{~m}, 1 \mathrm{H}), 1.04(\mathrm{~s}, 9 \mathrm{H}) ;{ }^{13} \mathrm{C} \mathrm{NMR}$ $\left(\mathrm{CDCl}_{3}\right) \delta 192.8,163.3,135.7,133.6,130.0,127.9,107.3,76.6,59.3,42.2,37.4,27.0,19.4$; FABHRMS $m / z 387.1980$ (calcd for $\mathrm{C}_{23} \mathrm{H}_{28} \mathrm{O}_{3} \mathrm{SiLi}[\mathrm{M}+\mathrm{Li}]^{+} \mathrm{m} / \mathrm{z}$ 387.1968).

Effect of Lewis acid: $\mathrm{ZnCl}_{2}$. The reaction of aldehyde 8 with diene 9 in the presence of $\mathrm{ZnCl}_{2}$ (1.0 $\mathrm{M}$ in ether, 1 equiv.) was carried out in ether at $-78^{\circ} \mathrm{C}$ for $9 \mathrm{~h}$, followed by $12 \mathrm{~h}$ at room temperature. Reaction of the residue with trifluoroacetic acid in $\mathrm{CH}_{2} \mathrm{Cl}_{2}$ was carried out as previously described. Purification of the crude product by chromatography gave 10 as a pale yellow oil (70\%).

Effect of Lewis acid: $\mathrm{TiCl}_{4}$. The reaction of aldehyde 8 with diene 9 in the presence of $\mathrm{TiCl}_{4}$ (1 equiv.) was carried out in ether at $-78^{\circ} \mathrm{C}$ for $9 \mathrm{~h}$, followed by $12 \mathrm{~h}$ at room temperature. Reaction of the residue with trifluoroacetic acid in $\mathrm{CH}_{2} \mathrm{Cl}_{2}$ was carried out as previously described. Purification of the crude product by chromatography gave 10 as a pale yellow oil (50\%).

Effect of Lewis acid: $\mathrm{MgBr}_{2}$. The reaction of aldehyde 8 with diene 9 in the presence of $\mathrm{MgBr}_{2}$ (1 equiv.) was carried out in ether at $-78^{\circ} \mathrm{C}$ for $9 \mathrm{~h}$, followed by $12 \mathrm{~h}$ at room temperature. Reaction of the residue with trifluoroacetic acid in $\mathrm{CH}_{2} \mathrm{Cl}_{2}$ was carried out as previously described. Purification of the crude product by chromatography gave 10 as a pale yellow oil (31\%).

Effect of chiral Lewis acid and chiral auxillary modified butadiene. The reaction of aldehyde 8 with 1-(1-Imenthyloxy)-3-(tert-butyldimethylsilyloxy)-1,3-butadiene ${ }^{6 b}$ in the presence of (+)-Eu(hfc) ${ }_{3}(0.05$ equiv.) was carried out in anhydrous hexane at room temperature. After $24 \mathrm{~h}, \mathrm{NEt}_{3}(4 \mathrm{~mL})$ and methanol $(2 \mathrm{~mL})$ were added and the mixture was concentrated under vacuum. Reaction of the residue with trifluoroacetic acid in $\mathrm{CH}_{2} \mathrm{Cl}_{2}$ was carried out as previously described. Purification of the crude product by chromatography gave $\mathbf{1 0}$ as a pale 
yellow oil (52\%). The ${ }^{1} \mathrm{H}$ NMR spectrum of this product was identical with that of rac-10: $[\alpha]_{D}=-4.1\left(c 1.32, \mathrm{CHCl}_{3}\right)$ [lit. ${ }^{2 e}[\alpha]_{D}=-35.8$ (c 1.0, $\left.\mathrm{CHCl}_{3}\right)$ 88\%ee].

Effect of Lewis acid: BINOL-Ti(iPrO) 4 . To a solution of $(R)-1,1^{\prime}$-binaphthol $(75.3 \mathrm{mg}, 0.263 \mathrm{mmol})$ in ether $(10 \mathrm{~mL})$ was added $4 \AA$ molecular sieves (526 mg). To this suspension was added dropwise, by syringe,

$\mathrm{Ti}(i \mathrm{PrO})_{4}(0.0374 \mathrm{~mL}, 0.127 \mathrm{mmol})$. The reaction mixture turned a reddish-brown in color. To the mixture was added a solution of $\mathrm{CF}_{3} \mathrm{CO}_{2} \mathrm{H}$ in $\mathrm{CH}_{2} \mathrm{Cl}_{2}(3 \mu \mathrm{L}, 0.5 \mathrm{M}, 0.15 \mathrm{mmol})$ and the reaction mixture was heated at reflux for $1 \mathrm{~h}$. After the mixture was cooled to room temperature, a solution of 8 (411 mg, $1.32 \mathrm{mmol})$ in ether $(5 \mathrm{~mL})$ was added dropwise. The resultant mixture was cooled to $-78{ }^{\circ} \mathrm{C}$ and $9(0.313 \mathrm{~mL})$ was added dropwise. The reaction mixture was stirred at $-78^{\circ} \mathrm{C}$ for $30 \mathrm{~min}$, and then stored in the freezer $\left(-5^{\circ} \mathrm{C}\right)$ for $48 \mathrm{~h}$. Saturated aqueous $\mathrm{NaHCO}_{3}(15 \mathrm{~mL})$ was added and the mixture was stirred for $45 \mathrm{~min}$. The mixture was filtered through filter-aid, the filter bed was washed with ether $(4 \times 25 \mathrm{~mL})$ and the combined organic layers dried $\left(\mathrm{MgSO}_{4}\right)$ and concentrated. Reaction of the residue with trifluoroacetic acid in $\mathrm{CH}_{2} \mathrm{Cl}_{2}$ was carried out as previously described. Purification of the crude product by chromatography gave 10 as a pale yellow oil $(19 \%)$. $[\alpha]_{D}=-39\left(c 0.84, \mathrm{CHCl}_{3}\right)$ $\left[\right.$ lit. $^{2 e}[\alpha]_{D}=-35.8\left(c 1.0, \mathrm{CHCl}_{3}\right) 88 \%$ ee $]$.

\subsubsection{8-Methyl glycoside (12)}

To a solution of dihydro-pyrone 10 (3.00 g, $7.89 \mathrm{mmol})$ in dry methanol $(25 \mathrm{~mL})$ was added, in one portion, $\mathrm{Hg}(\mathrm{OAc})_{2}(3.1 \mathrm{~g}, 9.7 \mathrm{mmol})$. The reaction mixture was stirred at $\mathrm{rt}$ for $6 \mathrm{~h}$, and the solvent was evaporated. The residue was dissolved in dry THF $(25 \mathrm{~mL})$ and cooled to $-78^{\circ} \mathrm{C}$. To the cooled solution was added, via syringe, a solution of $\mathrm{NaBH}_{3} \mathrm{CN}(0.2181 \mathrm{~g}, 3.471 \mathrm{mmol})$ in THF $(2 \mathrm{~mL})$. The reaction mixture was stirred for $4 \mathrm{~h}$, diluted with pentane and the solvent evaporated. The residue was purified by chromatography (hexane-ethyl acetate=19:1) to give 12 as a colorless oil $(2.204 \mathrm{~g}, 69 \%): R_{\mathrm{f}} 0.49$ (hexane-ethyl acetate=4:1); ${ }^{1} \mathrm{H}$ NMR $\left(\mathrm{CDCl}_{3}\right) \delta 7.67-7.61(\mathrm{~m}$, $4 \mathrm{H}), 7.46-7.34(\mathrm{~m}, 6 \mathrm{H}), 4.54(\mathrm{dd}, J=2.7,9.0 \mathrm{~Hz}, 1 \mathrm{H}), 3.95-3.85(\mathrm{~m}, 2 \mathrm{H}), 3.79(\mathrm{td}, J=5.1,10.2 \mathrm{~Hz}, 1 \mathrm{H}), 3.46(\mathrm{~s}, 3 \mathrm{H})$, 2.66 (ddd, J=2.6, 3.9, $14.8 \mathrm{~Hz}, 1 \mathrm{H}$ ), 2.43 (dd, J=9.7, $14.8 \mathrm{~Hz}, 1 \mathrm{H}$ ), 2.38 ( $\mathrm{br} \mathrm{d}, J=15.1 \mathrm{~Hz}, 1 \mathrm{H}$ ), 4H), 2.28 (dd, J=11.3, $15.1 \mathrm{~Hz}, 1 \mathrm{H}), 1.92-1.84(\mathrm{~m}, 2 \mathrm{H}), 1.04(\mathrm{~s}, 9 \mathrm{H}) ;{ }^{13} \mathrm{C} \mathrm{NMR}\left(\mathrm{CDCl}_{3}\right) \delta 205.9,135.7,133.8,129.9,127.9,101.2,68.2$, 59.7, 56.6, 48.1, 47.1, 38.9, 27.1, 19.4; FAB-HRMS $m / z$ 419.2238 (calcd for $\mathrm{C}_{24} \mathrm{H}_{32} \mathrm{O}_{4} \mathrm{SiLi}[\mathrm{M}+\mathrm{Li}]^{+} \mathrm{m} / \mathrm{z} 419.2230$ ). Anal. calcd for $\mathrm{C}_{24} \mathrm{H}_{32} \mathrm{O}_{4} \mathrm{Si}: \mathrm{C}, 69.86 ; \mathrm{H}, 7.82$. Found: $\mathrm{C}, 69.85 ; \mathrm{H}, 7.79$.

\subsubsection{Reduction of 12 with $\mathrm{LiAlH}(\mathrm{tBuO})_{3}$}

To a solution of $12(1.764 \mathrm{~g}, 4.275 \mathrm{mmol})$ in dry THF $(20 \mathrm{~mL})$ was added, in small portions over a $15 \mathrm{~min}$ period, solid $\mathrm{LiAlH}(\mathrm{OtBu})_{3}(1.358 \mathrm{~g}, 5.341 \mathrm{mmol})$. The reaction mixture was stirred at $\mathrm{rt}$ for $3 \mathrm{~h}$, at which time TLC analysis indicated complete consumption of $\mathbf{1 2}$. Water $(10 \mathrm{~mL})$ was cautiously added dropwise, the mixture was extracted with ether $(4 \times 50 \mathrm{~mL})$ and the combined extracts were dried $\left(\mathrm{MgSO}_{4}\right)$ and the solvent evaporated. The residue was purified by chromatography (hexane-ethyl acetate $=4: 1$ ) to give 13 as a colorless oil (1.640 $\mathrm{g}$, 92\%): $R_{\mathrm{f}} 0.12$ (hexane-ethyl acetate $=4: 1$ ); IR $\left(\mathrm{CHCl}_{3}, \mathrm{~cm}^{-1}\right) 3440 ;{ }^{1} \mathrm{H} \mathrm{NMR}\left(\mathrm{CDCl}_{3}\right) \delta 7.68-7.63(\mathrm{~m}, 4 \mathrm{H}), 7.46-7.34$ ( $\mathrm{m}, 6 \mathrm{H}), 4.26(\mathrm{dd}, J=1.9,9.5 \mathrm{~Hz}, 1 \mathrm{H}), 3.92-3.73(\mathrm{~m}, 3 \mathrm{H}), 3.60(\mathrm{br} \mathrm{m}, 1 / 2 \mathrm{~W}=26 \mathrm{~Hz}, 1 \mathrm{H}), 3.42(\mathrm{~s}, 3 \mathrm{H}), 2.17$

(tdd, $J=1.9,4.6,12.0 \mathrm{~Hz}, 1 \mathrm{H}), 1.92-1.78(\mathrm{~m}, 3 \mathrm{H}), 1.54(\mathrm{~d}, J=5.1 \mathrm{~Hz}, \mathrm{OH}), 1.42-1.33(\mathrm{~m}, 2 \mathrm{H}), 1.05(\mathrm{~s}, 9 \mathrm{H}) ;{ }^{13} \mathrm{C} \mathrm{NMR}$ $\left(\mathrm{CDCl}_{3}\right) \delta 135.7,134.0,129.8,127.8,101.2,68.6,67.2,60.2,56.5,41.1,40.9,38.6,27.0,19.4$; FAB-

HRMS $m / z 421.2381$ (calcd for $\mathrm{C}_{24} \mathrm{H}_{34} \mathrm{O}_{4} \mathrm{SiLi}[\mathrm{M}+\mathrm{Li}]^{+} \mathrm{m} / \mathrm{z}$ 421.2386). Anal. calcd for $\mathrm{C}_{24} \mathrm{H}_{34} \mathrm{O}_{4} \mathrm{Si}$ : C, 69.52; $\mathrm{H}, 8.26$. Found: C, 69.45; H, 8.17.

\subsubsection{Reduction of 12 with I-selectride}

A solution of I-selectride ( $2 \mathrm{~mL}, 1.0 \mathrm{M} \mathrm{THF}, 2.0 \mathrm{mmol})$ in dry THF $(8 \mathrm{~mL})$ was cooled to $-78^{\circ} \mathrm{C}$. To the cooled solution was added dropwise via syringe, over a period of $10 \mathrm{~min}$, a solution of 12 ( $371 \mathrm{mg}, 0.900 \mathrm{mmol}$ ) in dry $\operatorname{THF}(5 \mathrm{~mL})$. The reaction mixture was stirred for $3 \mathrm{~h}$, during which time the mixture was allowed to come to room temperature and TLC analysis indicated completion. Water $(8 \mathrm{~mL})$ was cautiously added dropwise, followed by $6 \mathrm{~N} \mathrm{NaOH}(0.6 \mathrm{~mL}), 30 \% \mathrm{H}_{2} \mathrm{O}_{2}(0.6 \mathrm{~mL})$ and aqueous $\mathrm{K}_{2} \mathrm{CO}_{3}(10 \mathrm{~mL})$. The mixture was extracted with 
ether $(3 \times 15 \mathrm{~mL})$ and the combined extracts were dried $\left(\mathrm{MgSO}_{4}\right)$ and the solvent evaporated. The residue was purified by chromatography (hexane-ethyl acetate $=4: 1$ ) to give a 1:1 mixture of $\mathbf{1 3}$ and $\mathbf{1 4}$ as a colorless oil (267 mg, 72\%). The axial alcohol 14 was only characterized as a mixture with 13.

14: $R_{\mathrm{f}} 0.12$ (hexane-ethyl acetate=4:1); ${ }^{1} \mathrm{H} \mathrm{NMR}\left(\mathrm{CDCl}_{3}\right.$, partial) $\delta 7.68-7.63(\mathrm{~m}, 4 \mathrm{H}), 7.46-7.34(\mathrm{~m}, 6 \mathrm{H}), 4.69$ (dd, J=2.1, 9.9 Hz, 1H), 4.31 (pentet, J=3.0 Hz, 1H), 4.22 (dd, J=4.4, 6.3 Hz, 1H), 3.42 (s, 3H), 1.92-1.20 (m, 7H), $1.05(\mathrm{~s}, 9 \mathrm{H})$.

\subsubsection{Acetoxy 6-methyl glycoside (15)}

To a solution of 13 (1.90 g, $4.582 \mathrm{mmol})$ in acetic anhydride $(20 \mathrm{~mL})$ was added sodium acetate $(0.3758 \mathrm{~g}$, $4.582 \mathrm{mmol}$ ). The reaction mixture was heated at reflux for $30 \mathrm{~min}$, diluted with water and extracted with ether $(4 \times 20 \mathrm{~mL})$. The combined ethereal extracts were repeatedly washed with saturated $\mathrm{NaHCO}_{3}$, followed by brine, dried $\left(\mathrm{MgSO}_{4}\right)$ and the solvent evaporated. The residue was purified by chromatography (hexane-ethyl acetate=9:1) to give 15 as a colorless oil $(1.924 \mathrm{~g}, 92 \%) ; \mathrm{IR}\left(\mathrm{CHCl}_{3}, \mathrm{~cm}^{-1}\right) 1740 ;{ }^{1} \mathrm{H} \mathrm{NMR}\left(\mathrm{CDCl}_{3}\right) \delta 7.69-7.64(\mathrm{~m}$, $4 \mathrm{H}), 7.46-7.34(\mathrm{~m}, 6 \mathrm{H}), 4.93(\mathrm{tt}, J=5.0,11.5 \mathrm{~Hz}, 1 \mathrm{H}), 4.33$ (dd, J=1.9, 9.8 Hz, $1 \mathrm{H}$ ), 3.89 (ddd, J=5.4, 8.1, $10.1 \mathrm{~Hz}$, $1 \mathrm{H}), 3.76(\mathrm{td}, J=5.1,10.2 \mathrm{~Hz}, 1 \mathrm{H}), 3.68(\mathrm{br} \mathrm{m}, 1 / 2 \mathrm{~W}=21 \mathrm{~Hz}, 1 \mathrm{H}), 3.43(\mathrm{~s}, 3 \mathrm{H}), 2.19$ (tdd, J=2.3, 4.8, $11.8 \mathrm{~Hz}, 1 \mathrm{H})$, $2.05(\mathrm{~s}, 3 \mathrm{H}), 1.96(\mathrm{br} \mathrm{dd}, J=5.0,12.2 \mathrm{~Hz}, 1 \mathrm{H}), 1.87-1.79(\mathrm{~m}, 2 \mathrm{H}), 1.43(\mathrm{dt}, J=9.7,11.9 \mathrm{~Hz}, 1 \mathrm{H}), 1.29$ (q, J=12.1 Hz, 1H), 1.06 (s, 9H); ${ }^{13} \mathrm{C} \mathrm{NMR}\left(\mathrm{CDCl}_{3}\right) \delta 171.0,135.7,134.0,129.8,127.8,101.0,69.1,68.4,60.0,56.5,38.6,37.3$, 37.0, 27.0, 21.4, 19.4; FAB-HRMS $\mathrm{m} / z 463.2489$ (calcd for $\mathrm{C}_{26} \mathrm{H}_{36} \mathrm{O}_{5} \mathrm{SiLi}$ [M+Li] ${ }^{+} \mathrm{m} / z$ 463.2492). Anal. calcd for $\mathrm{C}_{26} \mathrm{H}_{36} \mathrm{O}_{5} \mathrm{Si}: \mathrm{C}, 68.38 ; \mathrm{H}, 7.95$. Found: $\mathrm{C}, 68.38 ; \mathrm{H}, 7.92$.

\subsubsection{Allylation of 15 with TMSOTf}

A solution of $15(0.2244 \mathrm{~g}, 0.4913 \mathrm{mmol})$ in anhydrous $\mathrm{CH}_{3} \mathrm{CN}(5 \mathrm{~mL})$ was cooled to $0^{\circ} \mathrm{C}$. To the cooled solution was added allyltrimethylsilane $(5 \mathrm{~mL}, 3.6 \mathrm{~g}, 31 \mathrm{mmol})$. After stirring for $10 \mathrm{~min}$, trimethylsilyl triflate $(0.048 \mathrm{~mL}$, $0.055 \mathrm{~g}, 0.246 \mathrm{mmol}$ ) was added dropwise via syringe. The reaction mixture was stirred for ca. $15 \mathrm{~min}$, diluted with water, and extracted with ether. The combined ether extracts were dried $\left(\mathrm{MgSO}_{4}\right)$ and the solvent evaporated. The residue was purified by chromatography (hexane-ethyl acetate=9:1) to give $\mathbf{1 6}$ as a pale yellow oil $(0.1684 \mathrm{~g}, 73 \%): R_{\mathrm{f}} 0.65$ (hexane-ethyl acetate=9:1); ${ }^{1} \mathrm{H}$ NMR $\left(\mathrm{CDCl}_{3}\right) \delta 7.68-7.64(\mathrm{~m}, 4 \mathrm{H}), 7.46-7.35(\mathrm{~m}, 6 \mathrm{H})$, 5.77 (tdd, J=7.0, 10.3, $17.0 \mathrm{~Hz}, 1 \mathrm{H}), 5.07-4.80(\mathrm{~m}, 3 \mathrm{H}), 4.05-3.92(\mathrm{~m}, 2 \mathrm{H}), 3.84-3.67(\mathrm{~m}, 3 \mathrm{H}), 2.46(\mathrm{td}, \mathrm{J}=7.2$, $14.4 \mathrm{~Hz}, 1 \mathrm{H}), 2.23(\mathrm{td}, J=7.0,14.2 \mathrm{~Hz}, 1 \mathrm{H}), 2.04(\mathrm{~s}, 3 \mathrm{H}), 1.90-1.78(\mathrm{~m}, 2 \mathrm{H}), 1.72-1.62(\mathrm{~m}, 2 \mathrm{H}), 1.38(\mathrm{td}, \mathrm{J}=9.3$, $13.0 \mathrm{~Hz}, 1 \mathrm{H}), 1.05(\mathrm{~s}, 9 \mathrm{H}) ;{ }^{13} \mathrm{C} \mathrm{NMR}\left(\mathrm{CDCl}_{3}\right) \delta 170.8,135.8,134.9,134.1,129.8,127.9,117.3,70.9,67.7,66.0$, 60.5, 38.5, 37.1, 36.6, 33.9, 27.0, 21.6, 19.4; FAB-HRMS $m / z 473.2730$ (calcd for $\mathrm{C}_{28} \mathrm{H}_{38} \mathrm{O}_{4} \mathrm{SiLi}$ $[\mathrm{M}+\mathrm{Li}]^{+} \mathrm{m} / \mathrm{z}$ 473.2699). Anal. calcd for $\mathrm{C}_{28} \mathrm{H}_{38} \mathrm{O}_{4} \mathrm{Si}: \mathrm{C}, 72.05 ; \mathrm{H}, 8.21$. Found: $\mathrm{C}, 71.65 ; \mathrm{H}, 8.07$.

\subsubsection{Allylation of 15 with $\mathrm{BF}_{3} \cdot \mathrm{Et}_{2} \mathrm{O}$}

A solution of $15(95.4 \mathrm{mg}, 0.209 \mathrm{mmol})$ in dry $\mathrm{CH}_{2} \mathrm{Cl}_{2}(3 \mathrm{~mL})$ was cooled to $0^{\circ} \mathrm{C}$. To the cooled solution was added allyltrimethylsilane $(0.1 \mathrm{~mL}, 0.63 \mathrm{mmol})$. After stirring for $10 \mathrm{~min}, \mathrm{BF}_{3} \cdot \mathrm{Et}_{2} \mathrm{O}(0.04 \mathrm{~mL}, 0.4 \mathrm{mmol})$ was added dropwise via syringe. The reaction mixture was stirred for $20 \mathrm{~min}$ at $0^{\circ} \mathrm{C}$, and then warmed to room temperature and stirred for $3 \mathrm{~h}$, diluted with saturated aqueous $\mathrm{NaHCO}_{3}$, and extracted with $\mathrm{CH}_{2} \mathrm{Cl}_{2}(2 \times 10 \mathrm{~mL})$. The combined extracts were dried $\left(\mathrm{MgSO}_{4}\right)$ and the solvent evaporated. The residue was purified by chromatography (hexaneethyl acetate=19:1) to give 17 (30.1 mg, 35\%) followed by 16 (25.3 mg, 26\%) both as colorless oil.

17: $R_{\mathrm{f}} 0.78$ (hexane-ethyl acetate=19:1); ${ }^{1} \mathrm{H}$ NMR $\left(\mathrm{CDCl}_{3}\right) \delta 7.72-7.65(\mathrm{~m}, 4 \mathrm{H}), 7.46-7.35(\mathrm{~m}, 6 \mathrm{H}), 5.91-5.77(\mathrm{~m}$, 2H), $5.72(\mathrm{br} \mathrm{d}, J=10.2 \mathrm{~Hz}, 1 \mathrm{H}), 5.10-5.00(\mathrm{~m}, 2 \mathrm{H}), 4.16$ (br s, $1 \mathrm{H}), 3.98$ (dddd, J=4.2, 4.2, 8.4, 8.4 Hz, 1H), 3.89$3.71(\mathrm{~m}, 2 \mathrm{H}), 2.41(\mathrm{td}, J=7.2,14.1 \mathrm{~Hz}, 1 \mathrm{H}), 2.24(\mathrm{td}, J=7.1,14.1 \mathrm{~Hz}, 1 \mathrm{H}), 2.07-1.65(\mathrm{~m}, 4 \mathrm{H}), 1.06(\mathrm{~s}, 9 \mathrm{H})$. This product was not further characterized. 


\subsubsection{Aldehyde (19)}

A solution of $16(0.5200 \mathrm{~g}, 1.114 \mathrm{mmol})$ in dry $\mathrm{CH}_{2} \mathrm{Cl}_{2}(15 \mathrm{~mL})$ was cooled to $-78^{\circ} \mathrm{C}$ in a dry ice/acetone bath. The system was purged with carrier gas (compressed air) for $20 \mathrm{~min}$, and then ozone (generated from the compressed air with a Welsbach apparatus) was bubbled through the solution until a blue color persisted (ca. $15 \mathrm{~min}$ ). The system was purged with carrier gas until the blue color disappeared. Triphenylphosphine (1.39 $\mathrm{g}$, $5.31 \mathrm{mmol}$ ) was added and the mixture was stirred and allowed to warm to rt over a period of $2.5 \mathrm{~h}$. The reaction mixture diluted with brine and stirred for $10 \mathrm{~min}$. The mixture was extracted with $\mathrm{CH}_{2} \mathrm{Cl}_{2}(2 \times 10 \mathrm{~mL})$ and the combined extracts dried $\left(\mathrm{MgSO}_{4}\right)$, and concentrated. The residue was purified by chromatography (hexaneacetone, 9:1-4:1 gradient) to give 19 as a colorless oil $(0.4632 \mathrm{~g}, 89 \%) ;{ }^{1} \mathrm{H} \mathrm{NMR}\left(\mathrm{CDCl}_{3}\right) \delta 9.70(\mathrm{dd}, J=1.7,2.4 \mathrm{~Hz}$, 1H), 7.68-7.63 (m, 4H), 7.45-7.35 (m, 6H), $5.07(\mathrm{br} \mathrm{m}, 1 / 2 \mathrm{~W}=26 \mathrm{~Hz}, 1 \mathrm{H}), 4.54(\mathrm{~m}, 1 \mathrm{H}), 4.00(\mathrm{tt}, J=4.1,8.1 \mathrm{~Hz}, 1 \mathrm{H})$, 3.81-3.65 (m, 2H), 2.77 (ddd, J=2.5, 8.4, 16.4 Hz, 1H), 2.50 (ddd, J=1.7, 5.5, $16.4 \mathrm{~Hz}, 1 \mathrm{H}$ ), 2.04 (s, 3H), 2.01-1.90 (m, $2 \mathrm{H}), 1.80-1.64(\mathrm{~m}, 3 \mathrm{H}), 1.45(\mathrm{td}, \mathrm{J}=8.3,14.2 \mathrm{~Hz}, 1 \mathrm{H}), 1.04(\mathrm{~s}, 9 \mathrm{H})$. Anal. calcd for $\mathrm{C}_{27} \mathrm{H}_{36} \mathrm{O}_{5} \mathrm{Si}: \mathrm{C}, 69.19 ; \mathrm{H}, 7.74$. Found: $\mathrm{C}, 69.07 ; \mathrm{H}, 7.79$.

\subsubsection{Bis-pyran (20)}

To a solution of aldehyde $19(0.2101 \mathrm{~g}, 0.4489 \mathrm{mmol})$ in ether $(10 \mathrm{~mL})$ cooled to $-78^{\circ} \mathrm{C}$ was added dropwise 1methoxy-3-trimethylsilyloxy-1,3-butadiene $(0.127 \mathrm{~g}, 0.735 \mathrm{mmol})$ in ether $(5 \mathrm{~mL})$. After stirring for $5 \mathrm{~min}$, a solution of $\mathrm{ZnCl}_{2}(0.73 \mu \mathrm{L}, 1.0 \mathrm{M}$ in ether, $0.73 \mathrm{mmol})$ was added. The mixture was stirred for $3 \mathrm{~h}$ at $-78^{\circ} \mathrm{C}$, then warmed to room temperature and stirring was continued for $4 \mathrm{~h}$. Saturated aqueous $\mathrm{NaHCO}_{3}$ was added, the reaction was stirred for $30 \mathrm{~min}$, and then extracted with ether $(3 \times 10 \mathrm{~mL})$. The combined organic layers were dried $\left(\mathrm{MgSO}_{4}\right)$ and the solvent evaporated to afford a reddish brown oil. This residue was dissolved in

$\mathrm{CH}_{2} \mathrm{Cl}_{2}(15 \mathrm{~mL})$, trifluoroacetic acid (3 drops) was added, and the mixture stirred for $8 \mathrm{~h}$ at rt. Saturated aqueous $\mathrm{NaHCO}_{3}$ was added, the mixture stirred for $30 \mathrm{~min}$, the layers separated, and the aqueous layer extracted with $\mathrm{CH}_{2} \mathrm{Cl}_{2}(4 \times 10 \mathrm{~mL})$. The combined organic layers were dried $\left(\mathrm{MgSO}_{4}\right)$ and the solvent evaporated. The residue was purified by chromatography (hexane-ethyl acetate=9:1) to give 20 as a pale orange oil $(0.1092 \mathrm{mg}, \mathbf{4 5 \%}$ ). Analysis by ${ }^{1} \mathrm{H}$ NMR spectroscopy indicated that this is a mixture of diastereomers at $\mathrm{C} 11$ (ca. $\left.2: 1\right) ;{ }^{1} \mathrm{H}$ NMR $\left(\mathrm{CDCl}_{3}\right) \delta 7.65-7.60(\mathrm{~m}, 4 \mathrm{H}), 7.46-7.33(\mathrm{~m}, 6 \mathrm{H}), 7.20(\mathrm{~d}, \mathrm{~J}=6.1 \mathrm{~Hz}, 0.65 \mathrm{H})$ and $7.17(\mathrm{~d}, \mathrm{~J}=5.7 \mathrm{~Hz}, 0.35 \mathrm{H}), 5.36$ $(\mathrm{d}, J=6.1 \mathrm{~Hz})$ and $5.35(\mathrm{~d}, J=6.2 \mathrm{~Hz}$, total $1 \mathrm{H}), 5.08(\mathrm{~m}, 1 \mathrm{H}), 4.53(\mathrm{~m}, 1 \mathrm{H}), 4.26(\mathrm{~m}, 1 \mathrm{H}), 3.99(\mathrm{~m}, 1 \mathrm{H}), 3.81-3.62(\mathrm{~m}$, $2 \mathrm{H}), 2.53-2.32(\mathrm{~m}, 2 \mathrm{H}), 2.05(\mathrm{~s}, 3 \mathrm{H}), 2.01-1.92(\mathrm{~m}, 2 \mathrm{H}), 1.84-1.64(\mathrm{~m}, 3 \mathrm{H}), 1.45(\mathrm{td}, J=8.3,13.1 \mathrm{~Hz}, 1 \mathrm{H}), 1.02(\mathrm{~s}$, $9 \mathrm{H}$ ); El-HRMS $m / z 479.1887$ (calcd for $\mathrm{C}_{27} \mathrm{H}_{31} \mathrm{O}_{6} \mathrm{Si}[\mathrm{M}-t \mathrm{Bu}]^{+} \mathrm{m} / \mathrm{z} 479.1890$ ).

\subsubsection{Chiral allylation of 19}

To a solution of (-)- $\beta$-methoxydiisopinocampheylborane $(4.00 \mathrm{~g}, 12.6 \mathrm{mmol})$ in anhydrous toluene $(30 \mathrm{~mL})$ at $-78^{\circ} \mathrm{C}$ was added via syringe a solution of allylmagnesium bromide $(12.4 \mathrm{~mL}, 1.0 \mathrm{M}$ in ether, $12.4 \mathrm{mmol})$. The reaction mixture was stirred at $-78^{\circ} \mathrm{C}$ for $15 \mathrm{~min}$ and then warmed to room temperature over $1.5 \mathrm{~h}$. A white precipitate of magnesium salts formed during this time. The reaction mixture was transferred, via syringe, into four equal portions in four centrifuge tubes. After centrifugation, the salt-free solution was transferred into a second flask containing a solution of $19(2.26 \mathrm{~g}, 4.81 \mathrm{mmol})$ and $4 \AA \AA$ molecular sieves in anhydrous toluene $(10 \mathrm{~mL})$ at $-78^{\circ} \mathrm{C}$. The reaction mixture was stirred at $-78^{\circ} \mathrm{C}$ for $6 \mathrm{~h}$, and then slowly warmed to room temperature overnight. Proton NMR monitoring indicated disappearance of the starting aldehyde. Solid sodium perborate $(3.4 \mathrm{~g})$ and water $(5 \mathrm{~mL})$ were added and the resultant mixture was heated at reflux for $1 \mathrm{~h}$. After cooling to room temperature, brine was added and the reaction mixture stirred for $20 \mathrm{~min}$. The mixture was filtered through filter-aid and the filter bed washed with ether $(3 \times 100 \mathrm{~mL})$. The combined organic phases were dried $\left(\mathrm{MgSO}_{4}\right)$ and concentrated. The residue was purified by column chromatography (hexane-ethyl acetate=19:1) to give $22(1.044 \mathrm{~g}, 42 \%)$ followed by 23 (1.009 g, 41\%) both as colorless oils.

(-)-22: $R_{\mathrm{f}} 0.60$ (hexane-ethyl acetate=1:1); $[\alpha]_{\mathrm{D}}=-6.9$ (c 0.94, $\mathrm{CHCl}_{3}$ ); IR (neat) 3483, 3068, 1736, 1639, 989, $912 \mathrm{~cm}^{-1} ;{ }^{1} \mathrm{H}$ NMR $\left(\mathrm{CDCl}_{3}\right) \delta$ 7.65-7.60 (m, 4H), 7.46-7.33 (m, 6H), 5.82 (tdd, J=7.1, 10.8, $\left.16.5 \mathrm{~Hz}, 1 \mathrm{H}\right), 5.15-5.05$ 
$(\mathrm{m}, 3 \mathrm{H}), 4.21-4.07(\mathrm{~m}, 2 \mathrm{H}), 3.84-3.67(\mathrm{~m}, 3 \mathrm{H}), 3.16(\mathrm{OH}), 2.23(\mathrm{t}, J=6.4 \mathrm{~Hz}, 2 \mathrm{H}), 2.03$ and 2.06-1.94 (s and $\mathrm{m}$, $5 \mathrm{H}), 1.88-1.65(\mathrm{~m}, 4 \mathrm{H}), 1.52(\mathrm{td}, J=3.3,14.2 \mathrm{~Hz}, 1 \mathrm{H}), 1.48(\mathrm{td}, J=7.7,13.2 \mathrm{~Hz}, 1 \mathrm{H}), 1.06(\mathrm{~s}, 9 \mathrm{H}) ;{ }^{13} \mathrm{C} \mathrm{NMR}$ $\left(\mathrm{CDCl}_{3}\right) \delta 170.2,135.5,134.7,133.8,129.6,127.6,117.4,70.6,69.7,67.2,66.9,60.4,41.7,38.9,37.5,35.2,35.1$, 26.8, 21.2, 19.1. Anal. calcd for $\mathrm{C}_{30} \mathrm{H}_{42} \mathrm{O}_{5} \mathrm{Si}: \mathrm{C}, 70.55 ; \mathrm{H}, 8.29$. Found: $\mathrm{C}, 70.51 ; \mathrm{H}, 8.34$.

(+)-23: $R_{\mathrm{f}} 0.55$ (hexane-ethyl acetate=1:1); $[\alpha]_{D}=+21.9$ (c 1.00, $\mathrm{CHCl}_{3}$ ); IR (neat) 3457, 3068, 1736, 1644, 994, $917 \mathrm{~cm}^{-1} ;{ }^{1} \mathrm{H} \mathrm{NMR}\left(\mathrm{CDCl}_{3}\right) \delta 7.65-7.60(\mathrm{~m}, 4 \mathrm{H}), 7.46-7.33(\mathrm{~m}, 6 \mathrm{H}), 5.73(\mathrm{tdd}, \mathrm{J}=7.3,9.9,17.4 \mathrm{~Hz}, 1 \mathrm{H}), 5.13-5.02$ $(\mathrm{m}, 3 \mathrm{H}), 4.27(\mathrm{~m}, 1 \mathrm{H}), 3.98(\mathrm{tt}, J=4.2,8.4 \mathrm{~Hz}, 1 \mathrm{H}), 3.86-3.77(\mathrm{~m}, 2 \mathrm{H}), 3.70(\mathrm{~m}, 1 \mathrm{H}), 2.27-2.10(\mathrm{~m}, 2 \mathrm{H}), 2.04(\mathrm{~s}, 3 \mathrm{H})$, 2.00-1.85 (m, 3H), 1.77-1.64 (m, 3H), 1.47-1.35 (m, 2H), $1.04(\mathrm{~s}, 9 \mathrm{H})$, OH not observed; ${ }^{13} \mathrm{C} \mathrm{NMR}\left(\mathrm{CDCl}_{3}\right) \delta 170.3$, 135.5, 134.5, 133.8, 129.6, 127.6, 117.9, 67.6, 67.0, 66.8, 66.1, 60.4, 42.3, 38.8, 37.9, 35.8, 34.9, 26.8, 21.1, 19.1. Anal. calcd for $\mathrm{C}_{30} \mathrm{H}_{42} \mathrm{O}_{5} \mathrm{Si}: \mathrm{C}, 70.55 ; \mathrm{H}, 8.29$. Found: $\mathrm{C}, 70.25 ; \mathrm{H}, 8.35$.

\subsubsection{1. (R)-MTPA ester of 22}

To a solution of (-)-22 $(52.9 \mathrm{mg}, 0.104 \mathrm{mmol})$ in $\mathrm{CH}_{2} \mathrm{Cl}_{2}(8 \mathrm{~mL})$ was added $(R)$ - $\alpha$-methoxy(trifluoromethyl)phenyl acetic acid $(73.0 \mathrm{mg}, 0.310 \mathrm{mmol}), \operatorname{DMAP}(5.0 \mathrm{mg}, 0.04 \mathrm{mmol})$ and $\mathrm{DCC}(0.35 \mathrm{~mL}, 0.35 \mathrm{mmol})$. The reaction mixture was stirred for $3 \mathrm{~h}$, and then washed with $3 \%$ aqueous $\mathrm{HCl}$, followed by brine, dried $\left(\mathrm{MgSO}_{4}\right)$ and concentrated. The residue was purified by column chromatography (hexane-ethyl acetate=19:1) to give a colorless oil (45.4 mg, 60\%). Analysis by ${ }^{1} \mathrm{H}$ NMR spectroscopy indicated that the product was $>90 \%$ de: $R_{\mathrm{f}} 0.55$ (hexane-ethyl acetate=7:3); ${ }^{1} \mathrm{H}$ NMR $\left(\mathrm{CDCl}_{3}\right) \delta 7.68-7.63(\mathrm{~m}, 4 \mathrm{H}), 7.53-7.50(\mathrm{~m}, 2 \mathrm{H}), 7.41-7.34(\mathrm{~m}, 9 \mathrm{H}), 5.76-$ $5.62(\mathrm{~m}, 1 \mathrm{H}), 5.18-4.99(\mathrm{~m}, 4 \mathrm{H}), 4.01-3.90(\mathrm{~m}, 2 \mathrm{H}), 3.82-3.66(\mathrm{~m}, 3 \mathrm{H}), 3.51(\mathrm{~s}, 3 \mathrm{H}), 2.46-2.39(\mathrm{~m}, 2 \mathrm{H}), 2.03$ and 2.12-1.80 (s and $\mathrm{m}, 5 \mathrm{H}), 1.76-1.62(\mathrm{~m}, 4 \mathrm{H}), 1.37(\mathrm{td}, \mathrm{J}=9.0,13.1 \mathrm{~Hz}, 1 \mathrm{H}), 1.03(\mathrm{~s}, 9 \mathrm{H}) ;{ }^{13} \mathrm{C} \mathrm{NMR}\left(\mathrm{CDCl}_{3}\right) \delta 170.3$, $166.0,135.5,133.9,133.8,132.9,132.2,129.6,128.3,127.6,127.4,118.6,73.9,67.2,66.7,66.4,60.4,55.4$, $38.1,37.5,36.0,35.4,34.1,26.9,26.8,21.3,21.2,19.1$. This product was not further characterized.

\subsubsection{2. (S)-MTPA ester of 22}

The preparation of the (S)-MTPA ester of (-)-22 was carried out in the same fashion as the preparation of the $(R)$-MPTA ester (93\%). Analysis by ${ }^{1} \mathrm{H}$ NMR spectroscopy indicated that the product was $>90 \%$ de: $R_{\mathrm{f}} 0.55$ (hexane-ethyl acetate=7:3); ${ }^{1} \mathrm{H}$ NMR $\left(\mathrm{CDCl}_{3}\right) \delta 7.68-7.63(\mathrm{~m}, 4 \mathrm{H}), 7.52-7.49(\mathrm{~m}, 2 \mathrm{H}), 7.41-7.33(\mathrm{~m}, 9 \mathrm{H}), 5.62-$ $5.48(\mathrm{~m}, 1 \mathrm{H}), 5.18-4.94(\mathrm{~m}, 4 \mathrm{H}), 4.10-3.92(\mathrm{~m}, 2 \mathrm{H}), 3.84-3.68(\mathrm{~m}, 2 \mathrm{H}), 3.51(\mathrm{~s}, 3 \mathrm{H}), 2.45-2.27(\mathrm{~m}, 2 \mathrm{H}), 2.10(\mathrm{~m}$, $1 \mathrm{H}), 2.03$ and $2.03-1.82(\mathrm{~s}$ and $\mathrm{m}, 5 \mathrm{H}), 1.78-1.55(\mathrm{~m}, 4 \mathrm{H}), 1.45-1.32(\mathrm{~m}, 1 \mathrm{H}), 1.04(\mathrm{~s}, 9 \mathrm{H}) ;{ }^{13} \mathrm{C} \mathrm{NMR}$ $\left(\mathrm{CDCl}_{3}\right) \delta 170.5,165.9,135.5,133.9,133.8,132.9,132.5,132.2,129.6,128.3,127.6,127.4,118.6,73.8,67.2$, $66.8,66.5,60.5,55.4,38.0,37.4,35.9,34.2,26.9,26.8,21.2,19.2$. This product was not further characterized.

\subsubsection{3. (R)-MTPA ester of 23}

The preparation of the $(R)$-MTPA ester of $(+)-23$ was carried out in the same fashion as the preparation of the $(R)$-MPTA ester (-)-22 (47\%). Analysis by ${ }^{1} \mathrm{H}$ NMR spectroscopy indicated that the product was $>90 \%$ de: $R_{\mathrm{f}} 0.35$ (hexane-ethyl acetate $=4: 1) ;{ }^{1} \mathrm{H}$ NMR $\left(\mathrm{CDCl}_{3}\right) \delta 7.68-7.63(\mathrm{~m}, 4 \mathrm{H}), 7.52-7.50(\mathrm{~m}, 2 \mathrm{H}), 7.41-7.34(\mathrm{~m}, 9 \mathrm{H}), 5.71$ (tdd, J=7.1, 10.0, 17.0 Hz, 1H), 5.35-5.22 (m, 1H), 5.10-4.95 (m, 3H), 3.93-3.76 (m, 3H), 3.71 (td, J=5.3, $10.6 \mathrm{~Hz}$, $1 \mathrm{H}), 3.54(\mathrm{~s}, 3 \mathrm{H}), 2.42(\mathrm{~m}, 2 \mathrm{H}), 2.01$ and $2.06-1.75(\mathrm{~s}$ and $\mathrm{m}, 5 \mathrm{H}), 1.88-1.65(\mathrm{~m}, 4 \mathrm{H}), 1.45-1.20(\mathrm{~m}, 2 \mathrm{H}), 1.06(\mathrm{~s}$, $9 \mathrm{H})$. This product was not further characterized.

\subsubsection{4. (S)-MTPA ester of 23}

The preparation of the (S)-MTPA ester of (+)-23 was carried out in the same fashion as the preparation of the $(R)$-MPTA ester of (-)-22 (57\%). Analysis by ${ }^{1} \mathrm{H}$ NMR spectroscopy indicated that the product was $>90 \%$ de: $R_{\mathrm{f}} 0.29$ (hexane-ethyl acetate $\left.=4: 1\right) ;{ }^{1} \mathrm{H} \mathrm{NMR}\left(\mathrm{CDCl}_{3}\right) \delta 7.68-7.63(\mathrm{~m}, 4 \mathrm{H}), 7.52-7.50(\mathrm{~m}, 2 \mathrm{H}), 7.41-7.34(\mathrm{~m}$, $9 \mathrm{H}), 5.60(\mathrm{tdd}, J=7.2,10.1,17.4 \mathrm{~Hz}, 1 \mathrm{H}), 5.35-5.22(\mathrm{~m}, 1 \mathrm{H}), 5.10-4.95(\mathrm{~m}, 3 \mathrm{H}), 4.08(\mathrm{qd}, J=3.7,11.3 \mathrm{~Hz}, 1 \mathrm{H})$, 3.99-3.80 (m, 2H), $3.71(\mathrm{~m}, 1 \mathrm{H}), 3.58(\mathrm{~s}, 3 \mathrm{H}), 2.50-2.30(\mathrm{~m}, 2 \mathrm{H}), 2.03$ and 2.12-1.90 (s and $\mathrm{m}, 5 \mathrm{H}), 1.88-1.50(\mathrm{~m}$, $6 \mathrm{H}), 1.07(\mathrm{~s}, 9 \mathrm{H})$. This product was not further characterized. 


\subsubsection{Acrylate (-)-26}

To a solution of (-)-22 (105 mg, $0.206 \mathrm{mmol})$ in $\mathrm{CH}_{2} \mathrm{Cl}_{2}(5 \mathrm{~mL})$ at $0^{\circ} \mathrm{C}$ was triethylamine $(0.09 \mathrm{~mL}, 0.62 \mathrm{mmol})$ and DMAP $(2.5 \mathrm{mg}, 0.021 \mathrm{mmol})$. Acryloyl chloride $(0.02 \mathrm{~mL}, 0.25 \mathrm{mmol})$ was added via syringe and the solution was stirred at $0^{\circ} \mathrm{C}$ for $20 \mathrm{~min}$, and then warmed to room temperature and stirred for $2 \mathrm{~h}$. The reaction mixture was poured into a separatory funnel with saturated aqueous $\mathrm{NaHCO}_{3}$. The layers were separated and the aqueous layer was washed with methylene chloride $(3 \times 20 \mathrm{~mL})$. The combined organic layers were dried $\left(\mathrm{MgSO}_{4}\right)$ and concentrated. The residue was purified by column chromatography (hexane-ethyl acetate=4:1) to give (-)-26 as a colorless oil (60.3 mg, 52\%): $R_{\mathrm{f}} 0.27$ (hexane-ethyl acetate $\left.=4: 1\right),[\alpha]_{\mathrm{D}}=-4.0$ (c 1.26, $\left.\mathrm{CHCl}_{3}\right)$; IR 3073, 3042, 1788, 1726, 1636, 1619, 998, 989, 939, $919 \mathrm{~cm}^{-1} ;{ }^{1} \mathrm{H}$ NMR $\left(\mathrm{CDCl}_{3}\right) \delta 7.65-7.60(\mathrm{~m}, 4 \mathrm{H}), 7.46-7.33(\mathrm{~m}, 6 \mathrm{H}), 6.38$ (dd, J=1.3, 17.4 Hz, 1H), 6.09 (dd, J=10.1, 17.4 Hz, 1H), 5.79 (dd, J=1.5, $10.1 \mathrm{~Hz}, 1 \mathrm{H}$ ), 5.73 (tdd, J=6.9, 11.0, $16.5 \mathrm{~Hz}, 1 \mathrm{H}), 5.10-4.95(\mathrm{~m}, 4 \mathrm{H}), 4.07(\mathrm{br} \mathrm{m}, 1 \mathrm{H}), 3.97$ (dddd, J=2.9, 4.9, 7.9, 9.8 Hz, 1H), 3.85-3.67 (m, $2 \mathrm{H}), 2.37$ $(\mathrm{m}, 2 \mathrm{H}), 2.03(\mathrm{~s}, 3 \mathrm{H}), 2.10-1.64(\mathrm{~m}, 7 \mathrm{H}), 1.34(\mathrm{td}, \mathrm{J}=9.4,12.6 \mathrm{~Hz}, 1 \mathrm{H}), 1.05(\mathrm{~s}, 9 \mathrm{H}) ;{ }^{13} \mathrm{C} \mathrm{NMR}\left(\mathrm{CDCl}_{3}\right) \delta 170.3,165.5$, 135.5, 133.7, 133.2, 130.6, 129.5, 128.6, 127.6, 118.1, 70.9, 68.1, 67.3, 66.2, 60.4, 38.3, 38.2, 36.4, 35.7, 34.0, 26.8, 21.2, 19.1; FAB-HRMS $m / z$ 507.2187 (calcd for $\mathrm{C}_{29} \mathrm{H}_{35} \mathrm{O}_{6} \mathrm{Si}[\mathrm{M}-t \mathrm{Bu}]^{+} \mathrm{m} / z$ 507.2203).

\subsubsection{Acrylate (+)-27}

Reaction of acryloyl chloride with (+)-23 was carried out in a fashion similar to the preparation of acrylate ester of (-)-22 (52\%): $R_{\mathrm{f}} 0.53$ (hexane-ethyl acetate=7:3), $[\alpha]_{\mathrm{D}}=+30.2$ (c 1.06, $\mathrm{CHCl}_{3}$ ); IR 3073, 3037, 1739, 1726, 1634, 1614, 983, $917 \mathrm{~cm}^{-1} ;{ }^{1} \mathrm{H}$ NMR $\left(\mathrm{CDCl}_{3}\right) \delta 7.69-7.64(\mathrm{~m}, 4 \mathrm{H}), 7.43-7.34(\mathrm{~m}, 6 \mathrm{H}), 6.37(\mathrm{dd}, J=1.8,17.3 \mathrm{~Hz}, 1 \mathrm{H}), 6.09$ (dd, J=10.2, 17.3 Hz, 1H), 5.78 (dd, J=1.8, 10.3 Hz, 1H), 5.70 (tdd, J=7.1, 10.4, 17.3 Hz, 1H), $5.14(\mathrm{~m}, 1 \mathrm{H}$ ), 5.08$4.96(\mathrm{~m}, 3 \mathrm{H}), 4.12-4.04(\mathrm{~m}, 1 \mathrm{H}), 3.95-3.80(\mathrm{~m}, 2 \mathrm{H}), 3.67(\mathrm{td}, J=5.9,10.0 \mathrm{~Hz}, 1 \mathrm{H}), 2.35(\mathrm{~m}, 2 \mathrm{H}), 2.02$ and 2.09$1.90(\mathrm{~s}$ and $\mathrm{m}, 5 \mathrm{H}), 1.84-1.55(\mathrm{~m}, 5 \mathrm{H}), 1.33(\mathrm{td}, \mathrm{J}=9.7,12.7 \mathrm{~Hz}, 1 \mathrm{H}), 1.04(\mathrm{~s}, 9 \mathrm{H}) ;{ }^{13} \mathrm{C} \mathrm{NMR}\left(\mathrm{CDCl}_{3}\right) \delta 170.4,165.4$, 135.5, 133.9, 133.1, 130.4, 129.5, 128.7, 127.6, 118.1, 70.5, 67.6, 67.5, 65.6, 60.2, 39.1, 38.3, 36.4, 35.8, 34.9, 26.8, 21.2, 19.2; FAB-HRMS $m / z 571.3072$ (calcd for $\mathrm{C}_{33} \mathrm{H}_{44} \mathrm{O}_{6} \mathrm{SiLi}[\mathrm{M}+\mathrm{Li}]^{+} \mathrm{m} / \mathrm{z}$ 571.3067).

\subsubsection{Dihydropyran-2-one (-)-5}

To a solution of (-)-26 (57.2 $\mathrm{mg}, 0.101 \mathrm{mmol})$ in degassed $\mathrm{CH}_{2} \mathrm{Cl}_{2}(50 \mathrm{~mL})$ was added, via syringe, $\mathrm{Ti}(i \mathrm{PrO})_{4}(0.01 \mathrm{~mL}, 0.03 \mathrm{mmol})$. The reaction mixture was heated at reflux for $1 \mathrm{~h}$, and then cooled to room temperature. A solution of 'Grubbs' catalyst' $(16.7 \mathrm{mg}, 0.020 \mathrm{mmol})$ in $\mathrm{CH}_{2} \mathrm{Cl}_{2}(10 \mathrm{~mL})$ was added via cannula transfer at room temperature and the reaction mixture was stirred for $20 \mathrm{~h}$. The mixture was filtered through a small bed of silica gel and the filter bed washed with ethyl acetate $(3 \times 10 \mathrm{~mL})$. The combined organic layers were washed with brine, dried $\left(\mathrm{MgSO}_{4}\right)$ and concentrated. The residue was purified by column chromatography (hexane-ethyl acetate=7:3) to give (-)-5 as a colorless oil (39.9 mg, 73\%): $R_{\mathrm{f}} 0.065$ (hexane-ethyl acetate=7:3); $[\alpha]_{\mathrm{D}}=-38\left(\mathrm{c} 1.0, \mathrm{CHCl}_{3}\right) ; \mathrm{IR} 1731,704 \mathrm{~cm}^{-1} ;{ }^{1} \mathrm{H} \mathrm{NMR}\left(\mathrm{CDCl}_{3}\right) \delta 7.68-7.61(\mathrm{~m}, 4 \mathrm{H}), 7.46-7.32(\mathrm{~m}, 6 \mathrm{H}), 6.77$ (ddd, J=3.3, 5.3, $9.6 \mathrm{~Hz}, 1 \mathrm{H}), 5.97(\mathrm{br} \mathrm{d}, J=10.1 \mathrm{~Hz}, 1 \mathrm{H}), 5.06(\mathrm{tt}, J=4.5,9.0 \mathrm{~Hz}, 1 \mathrm{H}), 4.52(\mathrm{~m}, 1 \mathrm{H}), 4.24$ (dq, J=4.6, $9.1 \mathrm{~Hz}, 1 \mathrm{H}$ ), $3.97(\mathrm{tt}, J=4.2,8.4 \mathrm{~Hz}, 1 \mathrm{H}), 3.81-3.63(\mathrm{~m}, 2 \mathrm{H}), 2.36(\mathrm{~m}, 2 \mathrm{H}), 2.28$ (ddd, J=5.5, 9.3, $15.3 \mathrm{~Hz}, 1 \mathrm{H}), 2.03$ (s, 3H), $1.97(\mathrm{td}, J=3.1,12.7 \mathrm{~Hz}, 1 \mathrm{H}), 1.86-1.62(\mathrm{~m}, 5 \mathrm{H}), 1.39(\mathrm{td}, J=9.2,12.9 \mathrm{~Hz}, 1 \mathrm{H}), 1.02(\mathrm{~s}, 9 \mathrm{H}) ;{ }^{13} \mathrm{C} \mathrm{NMR}$ $\left(\mathrm{CDCl}_{3}\right) \delta 170.3,164.1,144.9,135.5,133.8,129.6,127.7,121.4,75.0,67.2,66.4,65.9,60.2,38.1,36.8,36.2$, 34.4, 28.7, 26.8, 21.2, 19.2; FAB-HRMS $m / z 479.1882$ (calcd for $\mathrm{C}_{27} \mathrm{H}_{31} \mathrm{O}_{6} \mathrm{Si}[\mathrm{M}-t \mathrm{Bu}]^{+} \mathrm{m} / \mathrm{z}$ 479.1890).

\subsubsection{Dihydropyran-2-one (+)-7}

The reaction of (+)-27 with Grubbs' catalyst (0.97 equiv.) in methylene chloride was carried out in a fashion similar to the ring closing metathesis of (-)-26, except that the reaction was run at room temperature for $20 \mathrm{~h}$. Work-up and purification as before gave (+)-7 as a colorless oil (89\%): $R_{\mathrm{f}} 0.14$ (hexane-ethyl acetate=7:3); $[\alpha]_{\mathrm{D}}=+7.7\left(c \mathrm{c} .16, \mathrm{CHCl}_{3}\right)$; IR 3067, 1726, $1235 \mathrm{~cm}^{-1} ;{ }^{1} \mathrm{H} \mathrm{NMR}\left(\mathrm{CDCl}_{3}\right) \delta 7.64-7.59(\mathrm{~m}, 4 \mathrm{H}), 7.44-7.33(\mathrm{~m}, 6 \mathrm{H}), 6.70$ (ddd, J=3.0, 5.5, 9.6 Hz, 1H), $5.94(\mathrm{dd}, J=2.5,9.7 \mathrm{~Hz}, 1 \mathrm{H}), 5.08(\mathrm{tt}, J=4.3,8.7 \mathrm{~Hz}, 1 \mathrm{H}), 4.57(\mathrm{~m}, 1 \mathrm{H}), 4.34(\mathrm{~m}, 1 \mathrm{H})$, 4.02 (tt, J=4.1, 8.4 Hz, 1H), 3.84 (ddd, J=4.0, 9.5, $9.8 \mathrm{~Hz}, 1 \mathrm{H}), 3.68(\mathrm{td}, J=4.9,10.2 \mathrm{~Hz}, 1 \mathrm{H}), 2.31-2.11(\mathrm{~m}, 2 \mathrm{H}), 2.04$ (s, 3H), 2.04-1.62 (m, 7H), 1.44 (td, J=8.2, $13.4 \mathrm{~Hz}, 1 \mathrm{H}), 1.02(\mathrm{~s}, 9 \mathrm{H}) ;{ }^{13} \mathrm{C} \mathrm{NMR}\left(\mathrm{CDCl}_{3}\right) \delta 170.4,164.0,144.8,135.4$, 
$133.9,133.6,129.6,127.6,121.3,74.4,67.3,65.5,65.4,60.0,38.0,37.7,35.8,35.0,29.8,26.8,21.3,19.2$. This product was not further characterized.

\subsubsection{Mitsunobu inversion of $(+)-23$}

To a stirred slurry of (+)-23 (358 mg, $0.702 \mathrm{mmol})$, triphenylphosphine (442 mg, $1.68 \mathrm{mmol})$, and $p$-nitrobenzoic acid $(282 \mathrm{mg}, 1.68 \mathrm{mmol})$ in toluene $(5 \mathrm{~mL})$ at $-30^{\circ} \mathrm{C}$ was added diethyl azodicarboxylate $(0.26 \mathrm{~mL}, 1.7 \mathrm{mmol})$. The reaction mixture was warmed to rt overnight. Saturated aqueous $\mathrm{NaHCO}_{3}$ was added and the layers were separated. The aqueous layer was extracted with ether $(4 \times 20 \mathrm{~mL})$ and the combined organic phases were dried $\left(\mathrm{MgSO}_{4}\right)$ and concentrated. Excess DEAD was removed by kugelrohr distillation and the residue was purified by column chromatography (hexane-ethyl acetate=7:3), to give (+)-28 $(0.286 \mathrm{~g}, 51 \%)$ as a pale yellow oil: $R_{\mathrm{f}} 0.77$ (hexane-ethyl acetate=1:1); $[\alpha]_{D}=+8.1\left(\right.$ c $\left.0.94, \mathrm{CHCl}_{3}\right) ;$ IR 3067, 3048, 1726, 1639, 1608, 1521, 1352, $921 \mathrm{~cm}^{-1} ;{ }^{1} \mathrm{H}$ $\operatorname{NMR}\left(\mathrm{CDCl}_{3}\right) \delta 8.25$ and $8.16\left(\mathrm{AA}^{\prime} \mathrm{BB}^{\prime}, \mathrm{J}=9.0 \mathrm{~Hz}, 4 \mathrm{H}\right), 7.68-7.63(\mathrm{~m}, 4 \mathrm{H}), 7.42-7.34(\mathrm{~m}, 6 \mathrm{H}), 5.78(\mathrm{tdd}, \mathrm{J}=7.1,10.1$, $17.1 \mathrm{~Hz}, 1 \mathrm{H}), 5.24(\mathrm{tt}, J=5.7,6.7 \mathrm{~Hz}, 1 \mathrm{H}), 5.13-5.01(\mathrm{~m}, 3 \mathrm{H}), 4.16-4.08(\mathrm{~m}, 1 \mathrm{H}), 4.02-3.92(\mathrm{~m}, 1 \mathrm{H}), 3.81-3.64(\mathrm{~m}$, $2 \mathrm{H}$ ), 2.57-2.40 (m, 2H), 2.23 (ddd, J=7.1, 8.6, $14.5 \mathrm{~Hz}, 1 \mathrm{H}), 2.02(\mathrm{~s}, 3 \mathrm{H}), 1.86-1.64(\mathrm{~m}, 5 \mathrm{H}), 1.43-1.19(\mathrm{~m}, 2 \mathrm{H})$, 1.03 (s, 9H); ${ }^{13} \mathrm{C} \mathrm{NMR}\left(\mathrm{CDCl}_{3}\right) \delta 170.3,164.0,150.4,135.7,135.5,133.7,132.9,130.6,129.5,127.6,123.4,118.5$, 72.7, 68.1, 67.2, 66.2, 60.3, 38.2, 38.0, 36.3, 35.7, 34.2, 26.7, 21.2, 19.1; FAB-HRMS m/z 666.3054 (calcd for $\left.\mathrm{C}_{37} \mathrm{H}_{45} \mathrm{O}_{8} \mathrm{NSiLi}[\mathrm{M}+\mathrm{Li}]^{+} \mathrm{m} / \mathrm{z} 666.3075\right)$.

\subsubsection{Hydrolysis of (+)-28}

A solution of (+)-28 $(78.5 \mathrm{mg}, 0.119 \mathrm{mmol})$ in saturated methanolic $\mathrm{K}_{2} \mathrm{CO}_{3}(10 \mathrm{~mL})$ was stirred at rt until TLC monitoring indicated complete comsumption of starting material. Aqueous $\mathrm{HCl}$ ( $1 \%$ by volume) was added until the solution was neutral. The reaction mixture was extracted with ether $(4 \times 25 \mathrm{~mL})$, and the combined organic layers were dried $\left(\mathrm{MgSO}_{4}\right)$ and concentrated. The residue was purified by column chromatography (hexaneethyl acetate $=1: 1)$ to give $(+)-29(40.3 \mathrm{mg}, 72 \%)$ as a colorless oil: $R_{\mathrm{f}} 0.17$ (hexane-ethyl acetate $\left.=1: 1\right) ;[\alpha]_{\mathrm{D}}=+9.4$ (c 0.73, $\left.\mathrm{CHCl}_{3}\right)$; IR 3396, $1107 \mathrm{~cm}^{-1}$; ${ }^{1} \mathrm{H}$ NMR $\left(\mathrm{CDCl}_{3}\right) \delta$ 7.69-7.64 (m, 4H), 7.45-7.36 (m, 6H), 5.89-5.75 $(\mathrm{m}, 1 \mathrm{H})$, 5.13-5.07 (m, 2H), 4.26-4.21 (m, 1H), 4.05-3.97 (m, 2H), 3.85-3.69 (m, 3H), 3.24 (OH), $2.23(\mathrm{t}, J=6.5 \mathrm{~Hz}, 1 \mathrm{H})$, 2.00-1.57 (m, 8H), $1.46(\mathrm{br} \mathrm{d}, \mathrm{J}=14.4 \mathrm{~Hz}, 1 \mathrm{H}), 1.35(\mathrm{td}, \mathrm{J}=7.9,13.0 \mathrm{~Hz}, 1 \mathrm{H}), 1.05(\mathrm{~s}, 9 \mathrm{H}) ;{ }^{13} \mathrm{C} \mathrm{NMR}\left(\mathrm{CDCl}_{3}\right) \delta 135.5$, $134.8,133.7,129.6,127.6,117.4,70.8,70.4,67.0,64.2,60.4,41.7,38.9,38.7,38.5,37.7,26.8,19.1$. This product was used in the next reaction without further characterizaton.

\subsubsection{Hydrolysis of (-)-22}

The hydrolysis of (-)-22 in saturated methanolic $\mathrm{K}_{2} \mathrm{CO}_{3}$ was carried out in a fashion similar to the hydrolysis of (+)-28 to give (-)-29 (88\%): The ${ }^{1} \mathrm{H}$ and ${ }^{13} \mathrm{C}$ NMR spectra of $(-)-29$ were identical with $(+)-29 .[\alpha]_{D}=-5.7$ (c 0.88, $\left.\mathrm{CHCl}_{3}\right)$.

\subsubsection{Bisacrylate (+)-30}

The bisacrylate ester (+)-30 (43\%) of (+)-29 was prepared in the same fashion as the acrylate ester of (-)22: $R_{\mathrm{f}} 0.78$ (hexane-ethyl acetate $\left.=1: 1\right),[\alpha]_{\mathrm{D}}=+15.5\left(c 0.976, \mathrm{CHCl}_{3}\right) ; \mathrm{IR} 3068,1726 \mathrm{~cm}^{-1} ;{ }^{1} \mathrm{H} \mathrm{NMR}\left(\mathrm{CDCl}_{3}\right) \delta 7.69-$ $7.64(\mathrm{~m}, 4 \mathrm{H}), 7.43-7.34(\mathrm{~m}, 6 \mathrm{H}), 6.40$ and $6.38(2 \times d d, J=1.6,17.2 \mathrm{~Hz}, 2 \mathrm{H}), 6.09(2 \times d d, J=10.3,17.3 \mathrm{~Hz}, 2 \mathrm{H}), 5.83$ and $5.79(2 \times d d, J=1.6,10.3 \mathrm{~Hz}, 1 \mathrm{H}), 5.74(\mathrm{~m}, 1 \mathrm{H}), 5.17-5.00(\mathrm{~m}, 2 \mathrm{H}), 4.15-4.05(\mathrm{~m}, 1 \mathrm{H}), 4.03-3.95(\mathrm{~m}, 1 \mathrm{H}), 3.85-$ $3.68(\mathrm{~m}, 2 \mathrm{H}), 2.38(\mathrm{~m}, 2 \mathrm{H}), 2.07(\mathrm{td}, \mathrm{J}=7.5,14.5 \mathrm{~Hz}, 1 \mathrm{H}), 2.00(\mathrm{br} \mathrm{d}, J=12.9 \mathrm{~Hz}, 1 \mathrm{H}), 1.90-1.65(\mathrm{~m}, 5 \mathrm{H}), 1.40$ (td, J=9.5, $12.7 \mathrm{~Hz}, 1 \mathrm{H}), 1.04(\mathrm{~s}, 9 \mathrm{H}) ;{ }^{13} \mathrm{C} \mathrm{NMR}\left(\mathrm{CDCl}_{3}\right) \delta 165.6,165.4,135.5,133.8,133.7,132.2,130.7,130.6$, $129.5,128.7,128.6,127.6,118.2,70.9,68.0,67.5,66.2,60.3,38.2,36.3,35.8,34.0,26.8,19.1$. This product was used in the next reaction without further characterizaton.

\subsubsection{Dihydropyran-2-one (+)-6}

The reaction of (+)-30 with Grubbs' catalyst (0.07 equiv.) in $\mathrm{CH}_{2} \mathrm{Cl}_{2}$ was carried out in a fashion similar to the ring closing metathesis of (-)-22, except that the reaction was run at room temperature for $48 \mathrm{~h}$. Work-up and purification as before gave (+)- 6 as a colorless oil (79\%): $R_{\mathrm{f}} 0.56$ (hexane-ethyl acetate $\left.=1: 1\right) ;[\alpha]_{\mathrm{D}}=+45.0(c 0.732$, 
$\left.\mathrm{CHCl}_{3}\right)$; IR $1721 \mathrm{~cm}^{-1} ;{ }^{1} \mathrm{H} \mathrm{NMR}\left(\mathrm{CDCl}_{3}\right) \delta 7.66-7.61(\mathrm{~m}, 4 \mathrm{H}), 7.45-7.34(\mathrm{~m}, 6 \mathrm{H}), 6.77(\mathrm{ddd}, \mathrm{J}=3.3,5.1,9.5 \mathrm{~Hz}, 1 \mathrm{H})$, 6.41 (dd, J=1.5, 17.4 Hz, 1H), 6.10 (dd, J=10.7, $17.4 \mathrm{~Hz}, 1 \mathrm{H}$ ), 5.98 (td, J=1.9, $9.6 \mathrm{~Hz}, 1 \mathrm{H}$ ), 5.85 (dd, J=1.6, $10.4 \mathrm{~Hz}$, $1 \mathrm{H}), 5.16(\mathrm{tt}, J=4.8,8.7 \mathrm{~Hz}, 1 \mathrm{H}), 4.53(\mathrm{~m}, 1 \mathrm{H}), 4.25(\mathrm{dq}, J=9.6,4.9 \mathrm{~Hz}, 1 \mathrm{H}), 4.00(\mathrm{tt}, J=4.1,8.0 \mathrm{~Hz}, 1 \mathrm{H}), 3.81-3.64$ $(\mathrm{m}, 2 \mathrm{H}), 2.39-2.24(\mathrm{~m}, 3 \mathrm{H}), 2.01(\mathrm{td}, J=3.5,13.0 \mathrm{~Hz}, 1 \mathrm{H}), 1.90-1.69(\mathrm{~m}, 5 \mathrm{H}), 1.45(\mathrm{td}, J=9.0,12.9 \mathrm{~Hz}, 1 \mathrm{H}), 1.03(\mathrm{~s}$, $9 \mathrm{H}) ;{ }^{13} \mathrm{C} \mathrm{NMR}\left(\mathrm{CDCl}_{3}\right) \delta 165.5,164.2,144.9,135.5,133.7,133.6,131.0,128.5,127.7,121.4,75.0,67.4,66.3,65.8$, 60.1, 38.0, 36.8, 36.0, 34.3, 28.6, 26.8, 19.1; FAB-HRMS $m / z$ 555.2747 (calcd for $\mathrm{C}_{32} \mathrm{H}_{40} \mathrm{O}_{6} \mathrm{SiLi}$

$\left.[\mathrm{M}+\mathrm{Li}]^{+} \mathrm{m} / \mathrm{z} 555.2754\right)$.

\section{Acknowledgements}

Financial support for this work was provided by the National Institutes of Health (GM-42641). The high resolution mass-spectral determinations were made at the Washington University Resource for Mass Spectrometry.

\section{References}

1. (a) P.A. Searle, T.F. Molinski, J. Am. Chem. Soc., 117 (1995), pp. 8126-8131 (b)

P.A. Searle, T.F. Molinski, L.J. Brzezinski, J.W. Leahy, J. Am. Chem. Soc., 118 (1996), pp. 9422-9423 (c)

T.F. Molinski, Tetrahedron Lett., 37 (1996), pp. 7879-7880

2. (a) C.S. Lee, C.J. Forsyth, Tetrahedron Lett., 37 (1996), pp. $6649-6652$ (b) R.D. Cink, C.J. Forsyth, J. Org. Chem., 62 (1997), pp. 5672-5673 (c) F. Ahmed, C.J. Forsyth, Tetrahedron Lett., 39 (1998), pp. 183-186 (d) D.A. Evans, V.J. Cee, T.E. Smith, K.J. Santiago, Org. Lett., 1 (1999), pp. 87-90 (e) A.B. Smith III, P.R. Verhoest, K.P. Minbiole, Org. Lett., 1 (1999), pp. 909-912 (f)

A.B. Smith III, K.P. Minbiole, P.R. Verhoest, T.J. Beauchamp, Org. Lett., 1 (1999), pp. 913-916 (g) D.R. Williams, M.P. Clark, M.A. Berliner, Tetrahedron Lett., 40 (1999), pp. 2287-2290 (h)

D.R. Williams, M.P. Clark, Tetrahedron Lett., 40 (1999), pp. 2291-2294 (i)

D.R. Williams, M.P. Clark, U. Emde, M.A. Berliner, Org. Lett., 2 (2000), pp. 3023-3026 (j)

T. Ye, G. Pattenden, Tetrahedron Lett., 39 (1998), pp. 319-322 (k)

G. Pattenden, A.T. Plowright, J.A. Tornos, T. Ye, Tetrahedron Lett., 39 (1998), pp. 6099-6102 (I)

G. Pattenden, A.T. Plowright, Tetrahedron Lett., 41 (2000), pp. 983-986 (m)

P. Wolbers, H.M.R. Hoffmann, Tetrahedron, 55 (1999), pp. 1905-1914 (n) P. Wolbers, H.M.R. Hoffmann, Synthesis (1999), pp. 797-802 (o) A.M. Misske, H.M.R. Hoffmann, Tetrahedron, 55 (1999), pp. 4315-4324 (p) P. Wolbers, A.M. Misske, H.M.R. Hoffmann, Tetrahedron Lett., 40 (1999), pp. 4527-4530 (q) P. Wolbers, H.M.R. Hoffmann, F. Sasse, Synlett (1999), pp. 1808-1810 (r) I. Paterson, E.A. Arnott, Tetrahedron Lett., 39 (1998), pp. 7185-7188 (s) S.D. Rychnovsky, C.R. Thomas, Org. Lett., 2 (2000), pp. 1217-1219 (t) J.V. Schaus, J.S. Panek, Org. Lett., 2 (2000), pp. 469-471 (u) J.D. White, C.L. Kranemann, P. Kuntiyong, Org. Lett., 3 (2001), pp. 4003-4006

3. (a) C.J. Forsyth, F. Ahmed, R.D. Cink, C.S. Lee, J. Am. Chem. Soc., 120 (1998), pp. 5597-5598 (b) D.A. Evans, V.J. Cee, T.E. Smith, D.M. Fitch, P.S. Cho, Angew. Chem., Int. Ed. Engl., 39 (2000), pp. 25332536 (c) D.A. Evans, D.M. Fitch, Angew. Chem., Int. Ed. Engl., 39 (2000), pp. 2536-2540 (d) D.A. Evans, D.M. Fitch, T.E. Smith, V.J. Cee, J. Am. Chem. Soc., 122 (2000), pp. 10033-10046 (e) A.B. Smith III, P.R. Verhoest, K.P. Minbiole, M. Schelhaas, J. Am. Chem. Soc., 123 (2001), pp. 4834-4836 (f) A.B. Smith III, K.P. Minbiole, P.R. Verhoest, M. Schelhaas, J. Am. Chem. Soc., 123 (2001), pp. 1094210953

4. Preliminary communication: P.B. Greer, W.A. Donaldson, Tetrahedron Lett., 41 (2000), pp. 3801-3803

5. (a) S. Danishefsky, M.T. Bilodeau, Angew. Chem., Int. Ed. Engl., 35 (1996), pp. 1380-1419 (b) S.J. Danishefsky, Aldrichimica Acta, 19 (1986), pp. 59-69 
6. (a) M. Bednarski, S. Danishefsky, J. Am. Chem. Soc., 108 (1986), pp. 7060-7067 (b)

S. Danishefsky, M. Bednarski, T. Izawa, C. Maring, J. Org. Chem., 49 (1984), pp. 2290-2292

7. G.E. Keck, X.-Y. Li, D. Krishnamurthy, J. Org. Chem., 60 (1995), pp. 5998-5999

8. S. Danishefsky, M. Langer, J. Org. Chem., 50 (1985), pp. 3672-3674

9. (a) M.D. Lewis, J.K. Cha, Y. Kishi, J. Am. Chem. Soc., 104 (1982), pp. 4976-4978 (b) I. Paterson, J.G. Cumming, Tetrahedron Lett., 33 (1992), pp. 2847-2850 (c) J.A.C. Romero, S.A. Tabacco, K.A. Woerpel, J. Am. Chem. Soc., 122 (2000), pp. 168-169

10. A. Hosomi, Y. Sakata, H. Sakurai, Tetrahedron Lett., 25 (1984), pp. 2383-2386

11. (a) F.E. Wincott, S.J. Danishefsky, G. Schulte, Tetrahedron Lett., 28 (1987), pp. 4951-4954 (b) S.J. Danishefsky, D.M. Armistead, F.E. Wincott, H.G. Selnick, R. Hungate, J. Am. Chem. Soc., 111 (1989), pp. 2967-2980

12. For other recent applications of this strategy see: (a) J. Cossy, D. Bauer, V. Bellosta, Tetrahedron Lett., 40 (1999), pp. 4187-4188 (b) A.K. Ghosh, C. Liu, Chem. Commun. (1999), pp. 1743-1744 (c) P.V. Ramachandran, M.V.R. Reddy, H.C. Brown, Tetrahedron Lett., 41 (2000), pp. 583-586 (d) T.J. Hunter, G.A. O'Doherty, Org. Lett., 3 (2001), pp. 2777-2780 (e) Y. Du, D.F. Weimer, Tetrahedron Lett., 42 (2001), pp. 6069-6072

13. (a) H.C. Brown, P.K. Jadhav, J. Am. Chem. Soc., 105 (1983), pp. 2092-2093 (b) U.S. Racherla, H.C. Brown, J. Org. Chem., 56 (1991), pp. 401-404

14. J.A. Dale, H.S. Mosher, J. Am. Chem. Soc., 95 (1973), pp. 512-519

15. O'Doherty and others, have noted that formation of acrylate esters using acryloyl chloride/NEt 3 gives only modest yields. ${ }^{12 d}$ The product can be formed in greater yield via coupling of the alcohol with acrylic acid in the presence of DCC.

16. R.H. Grubbs, Tetrahedron, 54 (1998), pp. 4413-4450

17. Due to an error in weighing, nearly 1 equiv. of Grubbs' catalyst was used in the preparation of (+)-7. It is anticipated that the reaction would proceed with catalytic amounts of this reagent, based on the preparations of (-)-5 and (+)-6.

18. (a) J.B. Nerenberg, D.T. Hung, P.K. Somers, S.L. Schreiber, J. Am. Chem. Soc., 115 (1993), pp. 12621-12622 (b) D.L. Boger, J. Hong, J. Am. Chem. Soc., 123 (2001), pp. 8515-8519

19. O. Mitsunobu, Synthesis (1981), pp. 1-28

20. A. Ndibwami, S. Lamothe, D. Guay, R. Plante, P. Soucy, S. Goldstein, P. Deslongchamps, Can. J. Chem., 71 (1993), pp. 695-712 